\title{
Crotalionosides A-C, Three New Megastigmane Glucosides, Two New Pterocarpan Glucosides and a Chalcone $C$-Glucoside from the Whole Plants of Crotalaria zanzibarica
}

\author{
Junko Shitamoto, ${ }^{a}$ Katsuyoshi Matsunami ${ }^{a}$ Hideaki Otsuka, ${ }^{* a}$ Takakazu Shinzato, ${ }^{b}$ and \\ Yoshio TAKEDA ${ }^{c}$ \\ ${ }^{a}$ Department of Pharmacognosy, Graduate School of Biomedical Sciences, Hiroshima University; 1-2-3 Kasumi, Minami- \\ ku, Hiroshima 734-8553, Japan: ${ }^{b}$ Subtropical Field Science Center, Faculty of Agriculture, University of the Ryukyus; 1 \\ Sembaru, Nakagami-gun, Okinawa 903-0213, Japan: and ${ }^{c}$ Faculty of Pharmacy, Yasuda Women's University; 6-13-1 \\ Yasuhigashi, Asaminami-ku, Hiroshima 731-0153, Japan.
}

Received March 3, 2010; accepted April 30, 2010; published online May 13, 2010

From a 1-BuOH-soluble fraction of the $\mathrm{MeOH}$ extract of the leaves of Crotalaria zanzibarica collected in the Okinawa Islands, three new megastigmane glucosides, named crotalionosides $\mathrm{A}-\mathrm{C}$, two new pterocarpan glucosides and a chalcone $C$-glucoside were isolated together with two known flavonoid glycosides and one known megastigmane glucoside. The structures of the new compounds were elucidated by a combination of spectroscopic analyses. The absolute configurations of allenic megastigmane glucosides were determined by application of the modified Mosher's method. Those of the allenic moieties were determined by interpretation of the circular dichroism (CD) spectra of the reduction products derived from citrosides $A$ and $B$. The aglycones of pterocarpan glucosides were found to be melilotocarpan $B$ and the absolute structure of the chalcone $C$-glucoside was determined by comparison of the $C D$ spectral behavior with the reported values.

Key words Crotalaria zanzibarica; Leguminosae; megastigmane glucoside; crotalionoside; pterocarpan glucoside; chalcone $C$ glucoside

The Crotalaria genus comprises about 350 species, which are mainly found in tropical areas. C. zanzibarica BenthAm (Leguminosae) $^{1)}$ (syn. C. usaramoensis BAKER f. $)^{2)}$ is a perennial shrubby herb and was introduced to the Okinawa Islands from Eastern Africa as a green manure crop. These days, this plant is widely found in the Okinawa Islands. It grows up to about $1.5 \mathrm{~m}$ in height and bears yellow flowers all year. Some pyrrolidine alkaloids, usaramine, ${ }^{3)}$ and usaramoensine, ${ }^{4}$ have been isolated from C. usaramoensis (synonym of C. zanzibarica). A related pyrrolidine alkaloid, integerrimine, has also been isolated from $C$. incana, ${ }^{4)}$ and monocrotaline and trichodesmine from C. sessiliflora. ${ }^{5)}$ From a 1-BuOH-soluble fraction, new megastigmane glucosides, named crotalionosides $\mathrm{A}-\mathrm{C}(\mathbf{1}-\mathbf{3})$, two pterocarpane glucosides $(\mathbf{4}, \mathbf{5})$, and a chalcone $C$-glucoside $(\mathbf{6})$ were isolated, together with three known compounds, 3-hydroxy-5,6epoxy- $\beta$-ionol 9- $O-\beta$-D-glucopyranoside (7), ${ }^{6}$ kaempferol 3 $O$-robinoside (8), ${ }^{77}$ and robinin (9) ${ }^{8}{ }^{8}$ This paper deals with structural elucidation of the new compounds and stereochemical discussion of allene-possessing megastigmane aglycones.

\section{Results and Discussion}

Air-dried whole plants of C. zanzibarica were extracted with $\mathrm{MeOH}$ three times and the concentrated $\mathrm{MeOH}$ extract was partitioned with solvents of increasing polarity. The 1$\mathrm{BuOH}$-soluble fraction was separated by means of various chromatographic procedures including column chromatography (CC) on a highly porous synthetic resin (Diaion HP-20), and then normal silica gel and reversed-phase octadecyl silica gel (ODS) CC, droplet counter-current chromatography (DCCC), and high-performance liquid chromatography (HPLC), which afforded nine compounds (1-9). The details and yields are given under Experimental. The structures of the new megastigmane glucosides, crotalionosides $\mathrm{A}-\mathrm{C}$
(1-3), pterocarpane glucosides $(4,5)$, and chalcone $C$-glucoside (6) were elucidated on the basis of spectroscopic evidence, and those of the known compounds (7-9) were identified by comparison of spectroscopic data with those reported in the literature.

Crotalionoside A $(\mathbf{1}),[\alpha]_{\mathrm{D}}^{21}-18.9^{\circ}$, was isolated as an amorphous powder and its elemental composition was determined to be $\mathrm{C}_{19} \mathrm{H}_{32} \mathrm{O}_{9}$ by high resolution (HR)-electrospray ionization (ESI)-mass spectrometry (MS). The IR spectrum indicated the presence of hydroxyl $\left(3367 \mathrm{~cm}^{-1}\right)$ and allenic groups $\left(1959 \mathrm{~cm}^{-1}\right)$. The prominent ${ }^{1} \mathrm{H}-\mathrm{NMR}$ resonances were assigned to three singlet methyls, one doublet methyl, one set of methylene protons $\left[\delta_{\mathrm{H}} 1.38(\mathrm{dd}, J=12,12 \mathrm{~Hz})\right.$ and $1.83(\mathrm{dd}, J=12,5 \mathrm{~Hz})]$, three oxymethine protons, one olefinic proton $\left(\delta_{\mathrm{H}} 5.35\right)$, and an anomeric proton. In the ${ }^{13} \mathrm{C}$ NMR spectrum, resonances for four methyls, one methylene, three oxymethines, two quaternary carbons and three olefinic carbons attributable to an allenic unit along with six signals assignable to a glucopyranose moiety were observed (Table 1). The above evidence indicates that crotalionoside A (1) is a derivative of megastigmane glucoside with an allenic unit and three hydoxyl groups, as shown in Fig. 1. Two proton sequences, $-\mathrm{CH}_{2}-\mathrm{CHO}(\mathrm{H})-\mathrm{CHO}(\mathrm{H})-$ and $=\mathrm{CH}-\mathrm{CHO}(\mathrm{H})-$ $\mathrm{CH}_{3}$, were observed in the ${ }^{1} \mathrm{H}-{ }^{1} \mathrm{H}$ correlation spectroscopy (COSY) spectrum, and the protons involed were correlated with the carbon signals in the heteronuclear single quantum coherence (HSQC) experiment. The heteronuclear multiple bond connectivity (HMBC) correlations from methyl protons on two gem-dimethyl groups with a methylene carbon placed the methylene carbon at the 2-position, and since the anomeric proton $\left(\delta_{\mathrm{H}} 4.62\right)$ showed a cross peak with one of the oxymethine carbons and the oxymethine proton $\left(\delta_{\mathrm{H}} 3.26\right)$ on the oxymethine carbon $\left(\delta_{\mathrm{C}} 91.7\right)$ showed a cross peak with the adjacent oxymethine proton $\left(\delta_{\mathrm{H}} 4.22\right)$ (Fig. 2), the glucosidic linkage was placed on the hydroxyl group at the 
Table 1. ${ }^{13} \mathrm{C}-\mathrm{NMR}$ Spectroscopic Data for Compounds $\mathbf{1}, \mathbf{2}$ and $\mathbf{3}$ $\left(\mathrm{CD}_{3} \mathrm{OD}, 100 \mathrm{MHz}\right)$

\begin{tabular}{rrrr}
\hline \hline C & $\mathbf{1}$ & $\mathbf{2}$ & $\mathbf{3}$ \\
\hline 1 & 35.5 & 35.6 & 44.5 \\
2 & 47.6 & 47.7 & 49.4 \\
3 & 69.5 & 69.5 & 76.8 \\
4 & 91.7 & 91.7 & 48.7 \\
5 & 74.9 & 74.9 & 82.3 \\
6 & 117.4 & 117.5 & 92.8 \\
7 & 201.0 & 200.9 & 126.7 \\
$8^{\prime}$ & 100.5 & 100.5 & 134.3 \\
9 & 67.2 & 67.2 & 78.1 \\
$1^{\prime}$ & 23.6 & 23.6 & 21.4 \\
11 & 29.4 & 29.4 & 25.9 \\
12 & 32.9 & 32.7 & 32.8 \\
$1^{\prime}$ & 27.1 & 27.2 & 31.6 \\
$1^{\prime}$ & 106.1 & 106.1 & 102.9 \\
$2^{\prime}$ & 76.2 & 76.2 & 75.5 \\
$3^{\prime}$ & 78.3 & 78.3 & 78.2 \\
$4^{\prime}$ & 71.6 & 71.6 & 71.5 \\
$5^{\prime}$ & 78.2 & 78.1 & 78.0 \\
$6^{\prime}$ & 62.8 & 62.8 & 62.8 \\
& & &
\end{tabular}

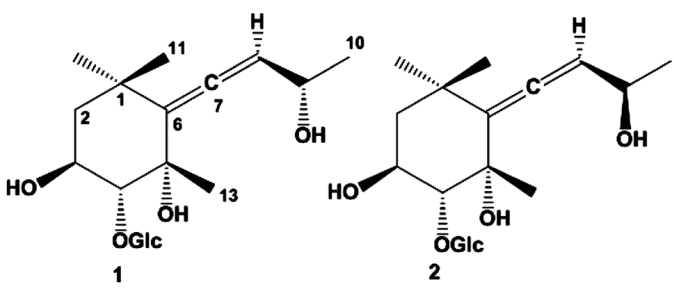<smiles>CC[C@]1(C)[C@H]2C[C@H](O)C[C@]1(C)O[C@H]2C</smiles><smiles>COC</smiles>

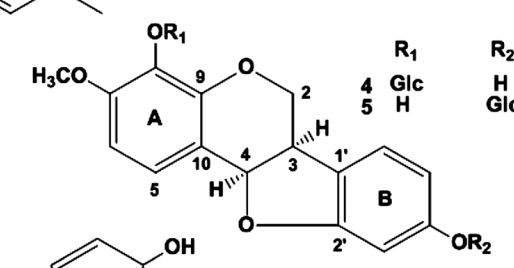<smiles>O=C([C](O)[C@@H](O)Cc1ccc(O)cc1)[C@H](O)Cc1ccc(O)cc1</smiles>

Fig. 1. Structures

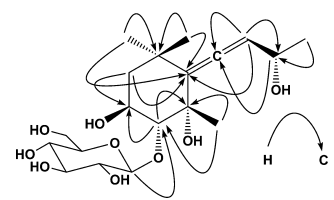

Fig. 2. HMBC Correlations of $\mathbf{1}$

4-position. Thus, the planar structure of crotalionoside A (1) was elucidated to be megastima-6,7-diene-3,4,5,9-tetrol 4- $O$ glucopyranoside (Fig. 1). The proton-proton coupling constant $(J=9 \mathrm{~Hz})$ of $\mathrm{H}-3$ and $\mathrm{H}-4$ indicated that these protons were in axial positions, and the significant correlation between $\mathrm{H}-4$ and $\mathrm{H}_{3}-13$ observed in the phase-sensitive (PS)-
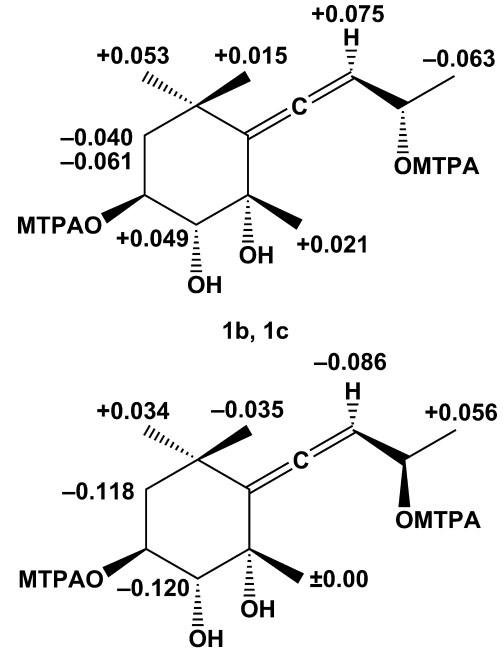

2b, 2c

Fig. 3. Results of Modified Mosher's Method $\left(\Delta_{\delta S-\delta R}\right)$

nuclear Overhauser effect spectroscopy (NOESY) spectrum revealed that these protons were on the same side. Enzymatic hydrolysis of crotalionoside A (1) gave an aglycone (1a) and glucose, which was found to be of the D-series from its positive optical rotation sign, and thus the mode of the glucosidic linkage was determined to be $\beta$ from the coupling constant of the anomeric proton $(J=8 \mathrm{~Hz})$. To the aglycone (1a), the modified Mosher's method was applied. ${ }^{9}(R)-$ and $(S)-\alpha$ Methoxy- $\alpha$-trifluoromethylphenyacetic acid (MTPA) derivatives $(\mathbf{1 b}, \mathbf{1 c})$ were prepared from the aglycone (1a) using 1ethyl-3-(3-dimethylaminopropyl)carbodiimide hydrochloride (EDC) and $N, N$-dimethyl-4-aminopyridine (4-DMAP), which afforded 3,9-diesters. As a result, the absolute configurations at the 3- and 9-positions were determined to $3 S$ and $9 S$, respectively (Fig. 3, 1b, 1c). In turn, those at the 4- and 5-positions were $R$ and $S$, respectively. The remaining stereochemical issue of the axis chirality in the allene part will be discussed later.

Crotalionoside $\mathrm{B}(2),[\alpha]_{\mathrm{D}}^{27}-12.1^{\circ}$, was isolated as an amorphous powder and its elemental compsotion was found to be the same as that of crotalionoside A (1). The physicochemical properties of crotalionoside B (2) were almost identical to those of $\mathbf{1}$ (Table 1), except for the optical rotation value. Since crotalionosides A and B $(\mathbf{1}, \mathbf{2})$ exhibited different retention times in the same HPLC run, they were unambiguously different compounds. As there was a probable chiral probe, $\beta$-D-glucopyranose, at the hydroxyl group of the ring moiety, the stereochemistry of $\mathbf{2}$ must be the same as that of 1, although the result of the modified Mosher's method, applied to its aglycone, did not show a regular distribution of signs. To clarify the stereochemsitry of the side chain, the aglycone (2a) of crotalionoside B (2), obtained by enzymatic hydrolysis, was analyzed by the modified Mosher's method, as shown in Fig. 3 (2b, 2c). The absolute configuration at the 9-position was revealed to be $R$, which was opposite to that of crotalionoside A (1).

Compounds structurally related to crotalionosides $\mathrm{A}$ and B (1, 2), citrosides A (10) and B (11), were first isolated from Citrus unshiu, and they are epimers as to the allene axis, $7 R$ and $7 S$, respectively. ${ }^{10)}$ Citrosides A (10) and B (11), 

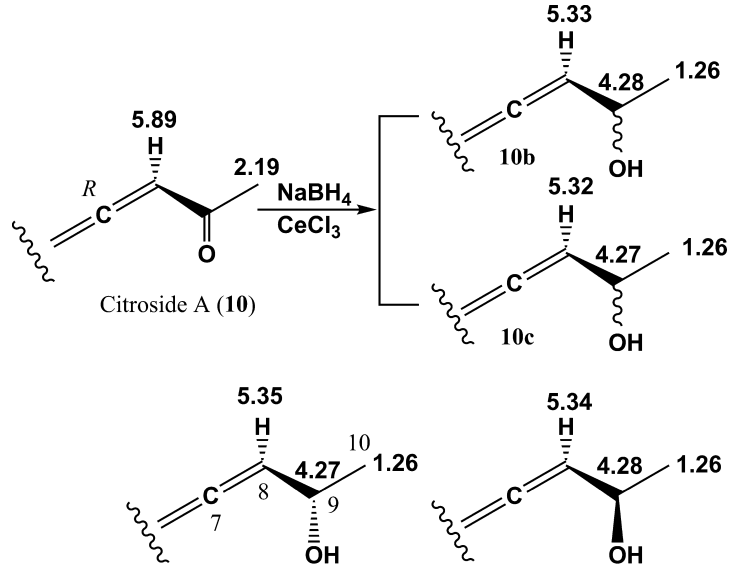

Crotalionoside A (1) Crotalionoside B (2)

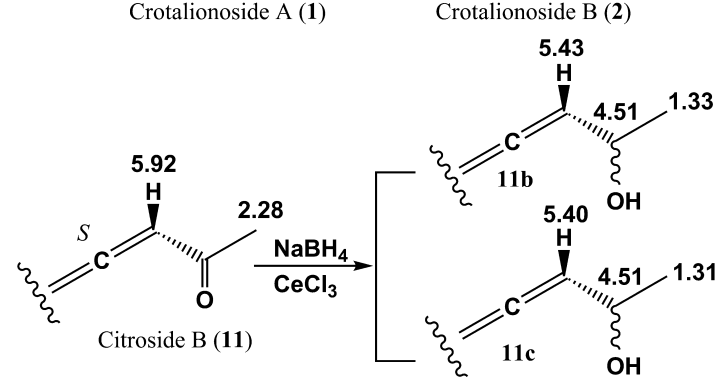

Fig. 4. Partial ${ }^{1} \mathrm{H}-\mathrm{NMR}$ Chemical Shifts for 10, 10b, 10c, 11, 11b and 11c

used in this experiment, were independently obtained from Elaeocarpus japonicus SIEBOLd et ZuCCARINI ${ }^{11)}$ and Sambucus chinensis Lindley, ${ }^{12)}$ respectively. Citrosides A (10) and B (11) were reduced with $\mathrm{NaBH}_{4}$ in the presence of $\mathrm{CeCl}_{3}$ to give the corresponding alcohols (10a, 11a). ${ }^{13)}$ In the circular dichroism (CD) spectra, an positive Cotton effect at $225 \mathrm{~nm}$ was observed for both alcohols, and the absorption position and sign of the Cotton effect were also the same as those of crotalionosides A (1) and B (2). Thus, CD spectral analyses were not effective for determining the absolute configuration of the allene axis. The alcohols (10a, 11a) comprised $R$ and $S$ mixtures as to the 9-position and they were separated by HPLC, which yielded pure compounds $\mathbf{1 0 b}$ and $\mathbf{1 0 c}$, and $\mathbf{1 1 b}$ and 11c, of which the absolute configurations at the 9-position remain uncertain. Figure 4 shows the ${ }^{1} \mathrm{H}-\mathrm{NMR}$ spectral data for $10 b$ and 10c, and 11b and 11c, the chemical shifts for $\mathrm{H}-8,9$ and 10 for $7 R$ compounds being essentially the same for $10 \mathbf{b}$ and $\mathbf{1 0 c}$, and those for $7 S$ compounds being different from those for $7 R$ compounds, but also essentially the same for 11b and 11c. These different chemical shifts solely depended upon the configurations at the 7-postition, that is, not upon those at the 9-positions. However, since determination of axis configurations of citrosides A (10) and B (11) still has some ambiguity, ${ }^{10,14)}$ the absolute configurations at the 7-positions of crotalionosides A (1) and B (2) were concluded to be the same as that of citroside A and tentatively assigned as $7 R$. Therefore, the structures of crotalionosides A (1) and B (2) were elucidated to be $(3 S, 4 R, 5 S, 7 R$, $9 S)$ - and $(3 S, 4 R, 5 S, 7 R, 9 R)$-megastigma-6,7-diene-3,4,5,9tetrol $4-O-\beta$-D-glucopyranosides, respectively, as shown in Fig. 1.

Crotalionoside $\mathrm{C}(\mathbf{3}),[\alpha]_{\mathrm{D}}^{25}+15.8^{\circ}$, was isolated as an amorphous powder and its elemental composition was deter-

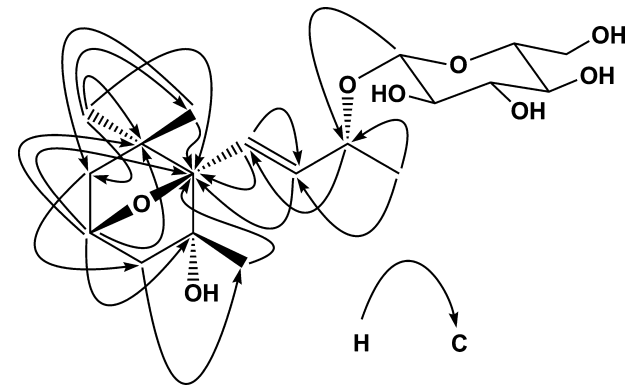

Fig. 5. HMBC Correlations of $\mathbf{3}$

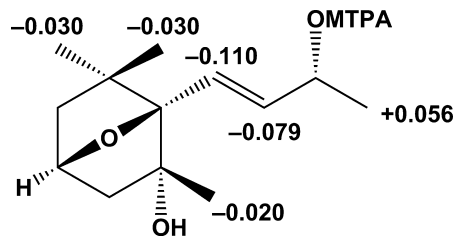

Fig. 6. Results of Modified Mosher's Method $\left(\Delta_{\delta S-\delta R}\right)$

mined to be $\mathrm{C}_{19} \mathrm{H}_{32} \mathrm{O}_{8}$. The ${ }^{13} \mathrm{C}$-NMR spectrum indicated the presence of 19 resonances, including six assignable to glucopyranose, and four methyl, two methylene, one trans double bond, two oxymethine, two oxygenated quarternary carbon and one quarternary carbon signals. The ${ }^{1} \mathrm{H}-{ }^{1} \mathrm{H}$ COSY spectrum exhibited two proton sequences, that is, A: $-\mathrm{C}(2) \mathrm{H}_{2}-\mathrm{C}(3) \mathrm{HO}(\mathrm{H})-\mathrm{C}(4) \mathrm{H}_{2}-$ and $\mathrm{B}:-\mathrm{C}(7) \mathrm{H}=\mathrm{C}(8) \mathrm{H}-$ $\mathrm{CH}(9) \mathrm{O}(\mathrm{H})-\mathrm{C}(10) \mathrm{H}_{3}$. In the $\mathrm{HMBC}$ spectrum, geminal methyl proton signals showed long-range correlation with a methylene carbon, $\mathrm{A}: \mathrm{C}(2)$ and an oxygen-bearing quaternary carbon $\left(\delta_{\mathrm{C}} 92.8\right)$, to which two olefinic protons $\left(\delta_{\mathrm{H}}\right.$ $5.78,5.80)$ also correlated (Fig. 5). From the degree of unsaturation, calculated from the elemental composition, other than the six-membered ring, crotalionoside C (3) was expected to possess one more cyclic system, whose presence was substantiated by the HMBC correlation cross peak between H-3 $\left(\delta_{\mathrm{H}} 4.33\right)$ and C-6 $\left(\delta_{\mathrm{C}} 92.8\right)$. The position of the sugar linkage was revealed to be at the hydroxyl group on the side chain by the HMBC spectrum and the mode of the linkage was determined to be $\beta$ from the coupling constant of the anomeric proton $\left(\delta_{\mathrm{H}} 4.36, J=8 \mathrm{~Hz}\right)$, together with the results of chirality analysis of glucose. From the above evidence, the structure of crotalionoside $\mathrm{C}$ (3) was assigned as megastagman-7-en-3,6-epoxy-5,9-diol 9- $O$ - $\beta$-D-glucopyranoside. Enzymatic hydrolysis of $\mathbf{3}$ gave an aglycone, crotalionol C (3a), and application of the modified Mosher's method to 3a established the absolute configuration at the 9-position to be $R$ (Fig. 6). However, the ring region lacks a clue for determing the absolute configuration. The PS-NOESY correlation between $\mathrm{H}_{3}-13\left(\delta_{\mathrm{H}} 1.19\right)$ and $\mathrm{H}-4 \mathrm{eq}\left(\delta_{\mathrm{H}} 1.95\right)$ revealed that the epoxy ring and $\mathrm{H}_{3}-13$ were on the same side, namely the ring has a $3 S^{*}, 5 R^{*}, 6 R^{*}$ relative configuration, as shown in Fig. 1.

Compound $4,[\alpha]_{\mathrm{D}}-65.6^{\circ}$, was isolated as an amorphous powder and its elemental composition was determined to be $\mathrm{C}_{22} \mathrm{H}_{24} \mathrm{O}_{10}$ by HR-ESI-MS. The IR spectrum indicated that compound 4 possessed aromatic rings (1615, 1505, $\left.1470 \mathrm{~cm}^{-1}\right)$ with a glycosidic moiety $\left(3388 \mathrm{~cm}^{-1}\right)$, the presence of the aromatic rings being also supported by the UV absorption at $282 \mathrm{~nm}$. In the ${ }^{1} \mathrm{H}-\mathrm{NMR}$ spectrum, four 


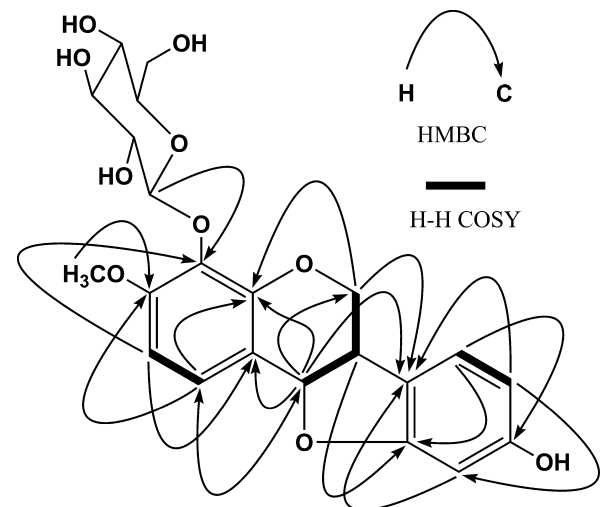

Fig. 7. H-H COSY and HMBC Correlations of $\mathbf{4}$

aliphatic proton signals, two aromatic proton signals coupled in an $\mathrm{AB}$ doublet system $\left[\delta_{\mathrm{H}} 6.78(\mathrm{~d}, J=9 \mathrm{~Hz})\right.$ and $7.24(\mathrm{~d}$, $J=9 \mathrm{~Hz}$ )], three aromatic proton signals coupled in an ABX system $\left[\delta_{\mathrm{H}} 6.24(\mathrm{~d}, J=2 \mathrm{~Hz}), 6.33(\mathrm{dd}, J=8,2 \mathrm{~Hz})\right.$, and 7.09 $(\mathrm{d}, J=8 \mathrm{~Hz})]$, one methoxy signal and an anomeric proton signal $\left[\delta_{\mathrm{H}} 4.90(\mathrm{~d}, J=8 \mathrm{~Hz})\right]$ were observed. The ${ }^{13} \mathrm{C}-\mathrm{NMR}$ spectrum exhibited 22 resonances, including six signals assignable to glucopyranose, 12 aromatic signals, and one methoxyl, one oxymethylene, one oxymethine and one methine signal. A sequence of oxymethylene, methine and oxymethine protons was observed in the ${ }^{1} \mathrm{H}-{ }^{1} \mathrm{H}$ COSY spectrum (Fig. 7). One of the aromatic rings was substituted with three oxygen atoms, and these substituted carbon atoms were correlated with methoxy, anomeric and oxymethylene protons in the HMBC spectrum. On irradiation of methoxyl protons, one $\left(\delta_{\mathrm{H}} 6.78\right)$ of the aromatic protons was signifcantly enhanced in the difference NOE experiment and this proton showed cross peaks with $\delta_{\mathrm{C}} 135.4$ (C-8) and 116.6 (C-10). The HMBC correlation from the oxymethine proton to $\mathrm{C}-10$ and other correlations shown in Fig. 7 revealed the structure of ring A. While the other trisubstituted aromatic ring possessed two oxygen atoms, and HMBC correlation cross peaks between oxymethylene protons and the quartenary carbon, $\delta_{\mathrm{C}} 119.2$, methine proton and oxygen bearing quartenary carbon, $\delta_{\mathrm{C}} 160.0$, together with other correlations suggested the structure of around B ring was as shown in Fig. 1. The above evidence substantiated that compound 4 was a 8 $O$-glucoside of pterocarpan, melilotocarpan B, isolated from Melilotus alba. ${ }^{15)}$ On enzymatic hydrolysis of 4, melilotocarpan B (4a) was obtained. The optical rotation value and sign of 4a showed good accordance with those reported in the literature. ${ }^{15)}$ Thus, compound $\mathbf{4}$ was concluded to have the $3 R, 4 R$ configuration. The negative Cotton effect at $234 \mathrm{~nm}$ observed in the CD spectrum also supported the configuration. Sugar analysis, using a chiral detector, revealed that the glucose was of the D-series and the coupling constant $(J=8 \mathrm{~Hz})$ of the anomeric proton established the mode of sugar linkage was $\beta$.

Compound 5, $[\alpha]_{\mathrm{D}}-94.1^{\circ}$, was isolated as an amorphous powder and its elemental composition was found to be the same as that of compound 4. Other spectroscopic data were similar to those for compound 4. In the HMBC spectrum, the anomeric proton $\left(\delta_{\mathrm{H}} 4.84\right)$ showed a cross peak with $\delta_{\mathrm{C}}$ 160.4 , to which was also correlated the aromatic proton, $\mathrm{H}-5^{\prime}$ $\left[\delta_{\mathrm{H}} 6.64(\mathrm{dd}, J=8,2 \mathrm{~Hz})\right]$. Sugar analysis also revealed that glucose was of the D-series. Thus, the structure of compound 5 was elucidated to be melilotocarpan $4^{\prime}-O-\beta$-D-glucopyranoside.

Compound 6, $[\alpha]_{\mathrm{D}}+61.5^{\circ}$, was isolated as an amorphous powder and its elemental composition was determined to be $\mathrm{C}_{21} \mathrm{H}_{24} \mathrm{O}_{10}$. The ${ }^{1} \mathrm{H}$ - and ${ }^{13} \mathrm{C}$-NMR spectroscopic data were essentially the same as those for coatline $\mathrm{A}$, which was isolated from Elysenhardtia polystachya by Beltrami et al. ${ }^{16}$ Although Beltrami et al. did not disscuss the stereochemistry of coatline A, compound $\mathbf{6}$ was expected to be a stereochemical isomer of coatline $\mathrm{A}\left([\alpha]_{\mathrm{D}}-45.2\right)$, since their optical rotation signs and values were opposite to each other. Thus, they are diastereomers, however, their NMR spectra were identical due to the remoteness of the chiral centers, such as the sugar moiety and $\alpha$-carbon. Augustyn et al. examined the CD spectra of enantioselectively synthesized $\alpha$-hydroxydihydrochalcones. ${ }^{17)}$ A similar compound, $(\alpha R)-\alpha, 2^{\prime} 4^{\prime}$-trihydroxy-4-methoxydihydrochalcone, (12) exhibited negative Cotton effect at $313 \mathrm{~nm}([\theta]-12000)$ and a positive one at $245 \mathrm{~nm}([\theta]+4000)$, which were opposite to those of compound 6. Thus, compound $\mathbf{6}$ has the $\alpha-S$ configuration and coatline A $\alpha-R$. This conclusion is in a good accord with that made by Alvarez and Delgado on determination of the $a b$ solute configuration of related $\alpha$-hydroxydihydrochalcone. ${ }^{18)}$

\section{Experimental}

General Experimental Procedures Mp was measured with a Yanagimoto micromelting point apparatus and is uncorrected. Optical rotations and CD spectra were measured on JASCO P-1030 and JASCO J-720 polarimeters, respectively. IR and UV spectra were measured on Horiba FT-710 and JASCO V-520 UV/Vis spectrophotometers, respectively. ${ }^{1} \mathrm{H}$ - and ${ }^{13} \mathrm{C}-\mathrm{NMR}$ spectra were taken on a JEOL JNM $\alpha-400$ spectrometer at $400 \mathrm{MHz}$ and $100 \mathrm{MHz}$, respectively, with tetramethylsilane as an internal standard. Positive-ion HR-MS were performed with an Applied Biosystem QSTAR XL system ESI-time-of-flight (TOF)-MS.

A highly-porous synthetic resin (Diaion HP-20) was purchased from Mitsubishi Kagaku (Tokyo, Japan). Silica gel CC and reversed-phase [octadecyl silica gel (ODS)] open CC were performed on silica gel 60 (Merck, Darmstadt, Germany) and Cosmosil $75 \mathrm{C}_{18}$-OPN (Nacalai Tesque, Kyoto, Japan) $\left[\Phi=50 \mathrm{~mm}, L=25 \mathrm{~cm}\right.$, linear gradient: $\mathrm{MeOH}-\mathrm{H}_{2} \mathrm{O}(1: 9$, $11) \rightarrow(1: 1,11)$, fractions of $10 \mathrm{~g}$ being collected], respectively. Droplet counter-current chromatography (DCCC) (Tokyo Rikakikai, Tokyo, Japan) was equipped with 500 glass columns $(\Phi=2 \mathrm{~mm}, L=40 \mathrm{~cm})$, and the lower and upper layers of a solvent mixture of $\mathrm{CHCl}_{3}-\mathrm{MeOH}-\mathrm{H}_{2} \mathrm{O}-n-\mathrm{PrOH}$ $(9: 12: 8: 2)$ were used for the stationary and mobile phases, respectively. Five-gram fractions were collected and numbered according to their order of elution with the mobile phase. HPLC was performed on an ODS column (Inertsil; GL Science, Tokyo, Japan; $\Phi=6 \mathrm{~mm}, L=25 \mathrm{~cm}$ ), and the eluate was monitored with a UV detector at $254 \mathrm{~nm}$ and a refractive index monitor.

Emulsin was purchased from Tokyo Chemical Industries Co., Ltd. (Tokyo, Japan), and crude hesperidinase was a gift from Tokyo Tanabe Pharmaceutical Co., Ltd. (Tokyo, Japan). $(R)$ - and $(S)$ - $\alpha$-MTPAs were the products of Wako Pure Chemical Industry Co., Ltd. (Tokyo, Japan).

Plant Material Whole plants of C. zanzibarica Bentham (Leguminosae) were collected in Kunigami-son, Kunigami-gun, Okinawa, Japan, in July 2003, and a voucher specimen was deposited in the Herbarium of Pharmaceutical Sciences, Graduate School of Biomedical Sciences, Hiroshima University (03-CZ-Okinawa-0630).

Extraction and Isolation Dried aerial parts of C. zanzibarica $(18.9 \mathrm{~kg})$ were extracted three times with $\mathrm{MeOH}(451)$ at $25^{\circ} \mathrm{C}$ for one week and then concentrated to 61 in vacuo. The extract was washed with $n$-hexane (61, $167 \mathrm{~g}$ ) and then the $\mathrm{MeOH}$ layer was concentrated to a gummy mass. The latter was suspended in water (61) and then extracted with EtOAc (61) to give $260 \mathrm{~g}$ of an EtOAc-soluble fraction. The aqueous layer was extracted with $1-\mathrm{BuOH}(61)$ to give a $1-\mathrm{BuOH}$-soluble fraction $(228 \mathrm{~g})$, and the remaining water-layer was concentrated to furnish $1.21 \mathrm{~kg}$ of a water-soluble fraction.

A portion $(96.8 \mathrm{~g})$ of the $1-\mathrm{BuOH}$-soluble fraction was subjected to a $\mathrm{Di}-$ aion $\mathrm{HP}-20$ column $(\Phi=60 \mathrm{~mm}, L=50 \mathrm{~cm})$ using $\mathrm{H}_{2} \mathrm{O}-\mathrm{MeOH}(4: 1,41)$, 
$(2: 3,41),(3: 2,41)$, and $(1: 4,41)$, and $\mathrm{MeOH}(41), 11$ fractions were being collected. The residue ( $15.4 \mathrm{~g}$ in fractions $3-6)$ of the $20-40 \% \mathrm{MeOH}$ eluent was subjected to silica gel $(500 \mathrm{~g}) \mathrm{CC}(\Phi=50 \mathrm{~mm}, L=50 \mathrm{~cm})$, with elution with $\mathrm{CHCl}_{3}-\mathrm{MeOH}[(9: 1,21),(4: 1,21)$, and $(3: 1,21)]$, $\mathrm{CHCl}_{3}-\mathrm{MeOH}-\mathrm{H}_{2} \mathrm{O}(35: 15: 2,21)$, and $\mathrm{MeOH}(21), 200 \mathrm{ml}$ fractions being collected. Combined fractions $18-23(1.02 \mathrm{~g})$ of the $20 \% \mathrm{MeOH}$ eluate were purified by ODS CC to give $88.4 \mathrm{mg}$ of 7 in fractions $118-124$. Combined fractions $24-30(735 \mathrm{mg})$ of the $20-30 \% \mathrm{MeOH}$ eluate were separated by ODS CC to give two fractions $(59.1 \mathrm{mg}$ in fractions $122-133$ and $32.6 \mathrm{mg}$ in fractions $134-144)$. Purification of the former by repeated HPLC $\left[\mathrm{MeOH}-\mathrm{H}_{2} \mathrm{O}(7: 13)\right.$ and then $\left.(11: 29)\right]$ afforded $0.5 \mathrm{mg}$ of $\mathbf{2}$. The latter was purified by HPLC $\left[\mathrm{MeOH}-\mathrm{H}_{2} \mathrm{O}(2: 3)\right]$ to give $3.7 \mathrm{mg}$ of 6 and $2.7 \mathrm{mg}$ of 1 from the peaks at $6 \mathrm{~min}$ and $10 \mathrm{~min}$, respectively. An aliquot $(2.5 \mathrm{~g})$ of combined fractions $31-40(4.02 \mathrm{~g})$ was subjected ODS CC and the residue $(89.1 \mathrm{mg})$ in $139-161$ was purified by DCCC. The residue $(8.8 \mathrm{mg})$ in fractions $37-45$ was finally purified by HPLC $\left[\mathrm{MeOH}-\mathrm{H}_{2} \mathrm{O}\right.$ ( $2: 3)$ ], $0.5 \mathrm{mg}$ of $\mathbf{2}$ and $1.8 \mathrm{mg}$ of $\mathbf{1}$ being yielded from the peaks at $7.5 \mathrm{~min}$ and $9 \mathrm{~min}$, respectively.

The residue $(12.7 \mathrm{~g})$ in fractions $7-10$, obtained from the $40 \% \mathrm{MeOH}$ eluate on Diaion HP-20 CC, was separated by silica gel $(600 \mathrm{~g}) \mathrm{CC}$ $(\Phi=58 \mathrm{~mm}, L=49 \mathrm{~cm})$, with elution with $\mathrm{CHCl}_{3}-\mathrm{MeOH}[(9: 1,31),(4: 1$, $31)$, and $(3: 1,31)], \mathrm{CHCl}_{3}-\mathrm{MeOH}-\mathrm{H}_{2} \mathrm{O}[(35: 15: 2,31)$ and $(65: 35: 4,31)$, and $\mathrm{MeOH}(31), 300 \mathrm{ml}$ fractions being collected. Combined fractions $9-$ $18(2.23 \mathrm{~g})$ were purified by ODS CC to give a residue $(150 \mathrm{mg}$ in fractions $142-152)$ and $65.8 \mathrm{mg}$ of 4 in fractions $157-161$. The residue was then purified by DCCC to give a residue $(17.1 \mathrm{mg}$ in fractions $80-88)$ and $40.6 \mathrm{mg}$ of 5 in fractions $108-115$. The residue was finally purified by HPLC $\left(\mathrm{MeOH}-\mathrm{H}_{2} \mathrm{O}, 37: 63\right)$ to give $5.3 \mathrm{mg}$ of $\mathbf{3}$ from the peak at $16 \mathrm{~min}$. Combined fractions $19-26(2.20 \mathrm{~g})$ were purified by ODS CC to give a residue (384 mg in fractions $75-84$ ) and $68.7 \mathrm{mg}$ of 9 . The residue was separated by DCCC to give $28.8 \mathrm{mg}$ of 6 in fractions $24-27$. On partial evaporation of combined fractions $32-46(5.70 \mathrm{~g}), 236 \mathrm{mg}$ of 8 was obtained as a yellow precipitate.

Crotalionoside A (1): Amorphous powder; $[\alpha]_{\mathrm{D}}^{21}-18.9^{\circ} \quad(c=0.19$, $\mathrm{MeOH}):$ IR $v_{\max }$ (film) $\mathrm{cm}^{-1}: 3367,2926,1959,1649,1454,1371,1076$, 1029; UV $\lambda_{\max }(\mathrm{MeOH}) \mathrm{nm}(\log \varepsilon): 208$ (3.32); ${ }^{1} \mathrm{H}-\mathrm{NMR} \quad\left(\mathrm{CD}_{3} \mathrm{OD}\right.$, $400 \mathrm{MHz}) \delta: 5.35(1 \mathrm{H}, \mathrm{d}, J=6 \mathrm{~Hz}, \mathrm{H}-8), 4.62\left(1 \mathrm{H}, \mathrm{d}, J=8 \mathrm{~Hz}, \mathrm{H}-1^{\prime}\right), 4.27$ $(1 \mathrm{H}, \mathrm{qd}, J=6,6 \mathrm{~Hz}, \mathrm{H}-9), 4.22(1 \mathrm{H}, \mathrm{ddd}, J=12,9,5 \mathrm{~Hz}, \mathrm{H}-3), 3.85(1 \mathrm{H}, \mathrm{dd}$, $\left.J=12,2 \mathrm{~Hz}, \mathrm{H}-6^{\prime} \mathrm{a}\right), 3.69$ (1H, dd, $\left.J=12,5 \mathrm{~Hz}, \mathrm{H}-6^{\prime} \mathrm{b}\right), 3.39\left(1 \mathrm{H}, \mathrm{m}, \mathrm{H}-5^{\prime}\right)$, $3.36\left(1 \mathrm{H}, \mathrm{dd}, J=9,9 \mathrm{~Hz}, \mathrm{H}-3^{\prime}\right), 3.33\left(1 \mathrm{H}, \mathrm{dd}, J=10,9 \mathrm{~Hz}, \mathrm{H}-4^{\prime}\right), 3.29(1 \mathrm{H}$, dd, $\left.J=9,8 \mathrm{~Hz}, \mathrm{H}-2^{\prime}\right), 3.27\left(1 \mathrm{H}, \mathrm{dd}, J=10,9 \mathrm{~Hz}, \mathrm{H}-3^{\prime}\right), 3.26(1 \mathrm{H}, \mathrm{d}, J=9 \mathrm{~Hz}$ $\mathrm{H}-4), 1.83(1 \mathrm{H}, \mathrm{dd}, J=12,5 \mathrm{~Hz}, \mathrm{H}-2 \mathrm{a}), 1.45\left(3 \mathrm{H}, \mathrm{s}, \mathrm{H}_{3}-13\right), 1.38(1 \mathrm{H}, \mathrm{dd}$, $J=12,12 \mathrm{~Hz}, \mathrm{H}-2 \mathrm{~b}), 1.31\left(3 \mathrm{H}, \mathrm{s}, \mathrm{H}_{3}-11\right), 1.26\left(3 \mathrm{H}, \mathrm{d}, J=6 \mathrm{~Hz}, \mathrm{H}_{3}-10\right), 1.06$ $\left(3 \mathrm{H}, \mathrm{s}, \mathrm{H}_{3}-12\right) ;{ }^{13} \mathrm{C}-\mathrm{NMR}\left(\mathrm{CD}_{3} \mathrm{OD}, 100 \mathrm{MHz}\right)$ : Table 1 ; $\mathrm{CD} \Delta \varepsilon(\mathrm{nm}):+2.46$ (224) $\left(c=3.01 \times 10^{-5} \mathrm{M}\right)$; HR-ESI-MS (positive-ion mode) $\mathrm{m} / \mathrm{z}$ : 427.1935 $[\mathrm{M}+\mathrm{Na}]^{+}$(Calcd for $\mathrm{C}_{19} \mathrm{H}_{32} \mathrm{O}_{9} \mathrm{Na}: 427.1938$ ).

Crotalionoside B (2): Amorphous powder; $[\alpha]_{\mathrm{D}}^{27}-12.1^{\circ} \quad(c=0.03$, $\mathrm{MeOH}):$ IR $v_{\max }$ (film) $\mathrm{cm}^{-1}: 3363,2925,1959,1453,1370,1074,1034$ UV $\lambda_{\max }(\mathrm{MeOH}) \mathrm{nm}(\log \varepsilon): 209$ (3.35); ${ }^{1} \mathrm{H}-\mathrm{NMR}\left(\mathrm{CD}_{3} \mathrm{OD}, 400 \mathrm{MHz}\right) \delta$ $5.34(1 \mathrm{H}, \mathrm{d}, J=6 \mathrm{~Hz}, \mathrm{H}-8), 4.62\left(1 \mathrm{H}, \mathrm{d}, J=8 \mathrm{~Hz}, \mathrm{H}-1^{\prime}\right), 4.28(1 \mathrm{H}, \mathrm{qd}, J=6$, $6 \mathrm{~Hz}, \mathrm{H}-9), 4.21(1 \mathrm{H}$, ddd, $J=12,9,5 \mathrm{~Hz}, \mathrm{H}-3), 3.84(1 \mathrm{H}, \mathrm{dd}, J=12,2 \mathrm{~Hz}$, H-6' a), $3.69\left(1 \mathrm{H}, \mathrm{dd}, J=12,5 \mathrm{~Hz}, \mathrm{H}-6^{\prime} \mathrm{b}\right), 3.39\left(1 \mathrm{H}, \mathrm{m}, \mathrm{H}-5^{\prime}\right), 3.33(1 \mathrm{H}, \mathrm{dd}$ $\left.J=10,9 \mathrm{~Hz}, \mathrm{H}-4^{\prime}\right), 3.29\left(1 \mathrm{H}, \mathrm{dd}, J=9,8 \mathrm{~Hz}, \mathrm{H}-2^{\prime}\right), 3.27(1 \mathrm{H}, \mathrm{dd}, J=10$, $\left.9 \mathrm{~Hz}, \mathrm{H}-3^{\prime}\right), 3.26(1 \mathrm{H}, \mathrm{d}, J=9 \mathrm{~Hz}, \mathrm{H}-4), 1.83(1 \mathrm{H}, \mathrm{dd}, J=12,5 \mathrm{~Hz}, \mathrm{H}-2 \mathrm{a})$ $1.44\left(3 \mathrm{H}, \mathrm{s}, \mathrm{H}_{3}-13\right), 1.38(1 \mathrm{H}, \mathrm{dd}, J=12,12 \mathrm{~Hz}, \mathrm{H}-2 \mathrm{~b}), 1.31\left(3 \mathrm{H}, \mathrm{s}, \mathrm{H}_{3}-11\right)$, $1.26\left(3 \mathrm{H}, \mathrm{d}, J=6 \mathrm{~Hz}, \mathrm{H}_{3}-10\right), 1.07\left(3 \mathrm{H}, \mathrm{s}, \mathrm{H}_{3}-12\right) ;{ }^{13} \mathrm{C}-\mathrm{NMR}\left(\mathrm{CD}_{3} \mathrm{OD}\right.$ $100 \mathrm{MHz}):$ Table 1; CD $\Delta \varepsilon(\mathrm{nm}):+3.55(225)\left(c=2.98 \times 10^{-5} \mathrm{M}\right)$; HR-ESIMS (positive-ion mode) $m / z$ : $427.1936[\mathrm{M}+\mathrm{Na}]^{+}$(Calcd for $\mathrm{C}_{19} \mathrm{H}_{32} \mathrm{O}_{9} \mathrm{Na}$ 427.1938).

Crotalionoside C (3): Amorphous powder; $[\alpha]_{\mathrm{D}}^{25}+15.8^{\circ}(c=0.31$, $\mathrm{MeOH}$ ); IR $v_{\max }$ (film) $\mathrm{cm}^{-1}: 3395,2970,1368,1305,1243,1074,1036$ ${ }^{1} \mathrm{H}-\mathrm{NMR}\left(\mathrm{CD}_{3} \mathrm{OD}, 400 \mathrm{MHz}\right) \delta: 5.80(1 \mathrm{H}, \mathrm{d}, J=16 \mathrm{~Hz}, \mathrm{H}-7), 5.78(1 \mathrm{H}, \mathrm{dd}$ $J=16,5 \mathrm{~Hz}, \mathrm{H}-8), 4.39(1 \mathrm{H}, \mathrm{qd}, J=6,5 \mathrm{~Hz}, \mathrm{H}-9), 4.36(1 \mathrm{H}, \mathrm{d}, J=8 \mathrm{~Hz}, \mathrm{H}-$ $\left.1^{\prime}\right), 4.33(1 \mathrm{H}, \mathrm{br}$ dd, $J=6,6 \mathrm{~Hz}, \mathrm{H}-3), 3.81$ (1H, dd, $\left.J=12,2 \mathrm{~Hz}, \mathrm{H}-6^{\prime} \mathrm{a}\right), 3.66$ $\left(1 \mathrm{H}, \mathrm{dd}, J=12,5 \mathrm{~Hz}, \mathrm{H}-6^{\prime} \mathrm{b}\right), 3.39\left(1 \mathrm{H}, \mathrm{dd}, J=9,9 \mathrm{~Hz}, \mathrm{H}-3^{\prime}\right), 3.35(1 \mathrm{H}, \mathrm{m}$, $\left.\mathrm{H}-5^{\prime}\right), 3.32\left(1 \mathrm{H}, \mathrm{dd}, J=9,9 \mathrm{~Hz}, \mathrm{H}-4^{\prime}\right), 3.18\left(1 \mathrm{H}, \mathrm{dd}, J=9,8 \mathrm{~Hz}, \mathrm{H}-2^{\prime}\right), 1.95$ $(1 \mathrm{H}$, ddd, $J=12,6,2 \mathrm{~Hz}, \mathrm{H}-4 \mathrm{a}), 1.77$ (1H, ddd, $J=12,6,2 \mathrm{~Hz}, \mathrm{H}-2 \mathrm{a}), 1.64$ $(1 \mathrm{H}, \mathrm{dd}, J=12,6 \mathrm{~Hz}, \mathrm{H}-4 \mathrm{~b}), 1.59(1 \mathrm{H}, \mathrm{d}, J=12 \mathrm{~Hz}, \mathrm{H}-2 \mathrm{~b}), 1.40\left(3 \mathrm{H}, \mathrm{s}, \mathrm{H}_{3}\right.$ 11), $1.30\left(3 \mathrm{H}, \mathrm{d}, J=6 \mathrm{~Hz}, \mathrm{H}_{3}-10\right), 1.19\left(3 \mathrm{H}, \mathrm{s}, \mathrm{H}_{3}-13\right), 0.58\left(3 \mathrm{H}, \mathrm{s}, \mathrm{H}_{3}-12\right)$ ${ }^{13} \mathrm{C}-\mathrm{NMR}\left(\mathrm{CD}_{3} \mathrm{OD}, 100 \mathrm{MHz}\right)$ : Table 1; HR-ESI-MS (positive-ion mode) $m / z: 411.1993[\mathrm{M}+\mathrm{Na}]^{+}\left(\right.$Calcd for $\mathrm{C}_{19} \mathrm{H}_{32} \mathrm{O}_{8} \mathrm{Na}: 411.1989$ ).

Compound 4: Amorphous powder; $[\alpha]_{\mathrm{D}}^{25}-65.6^{\circ}(c=0.16, \mathrm{MeOH})$; IR $V_{\max }$ (film) $\mathrm{cm}^{-1}: 3388,2897,1615,1505,1470,1288,1099,1027,800$; UV $\lambda_{\max }(\mathrm{MeOH}) \mathrm{nm}(\log \varepsilon): 282(3.56), 230 \mathrm{sh}(3.90), 212$ (4.21); ${ }^{1} \mathrm{H}-\mathrm{NMR}$
Table 2. ${ }^{13} \mathrm{C}-\mathrm{NMR}$ Spectroscopic Data for Pterocarpans $(\mathbf{4}, \mathbf{5})$ and Chalcone (6) $\left(\mathrm{CD}_{3} \mathrm{OD}, 100 \mathrm{MHz}\right)$

\begin{tabular}{|c|c|c|c|}
\hline C & 4 & 5 & 6 \\
\hline 1 & & & 129.3 \\
\hline 2 & 68.2 & 67.9 & 131.6 \\
\hline 3 & 41.0 & 41.2 & 116.2 \\
\hline 4 & 79.8 & 80.2 & 157.2 \\
\hline 5 & 127.8 & 122.1 & 116.2 \\
\hline 6 & 107.7 & 107.1 & 131.6 \\
\hline 7 & 154.6 & 150.0 & \\
\hline 8 & 135.4 & 135.8 & \\
\hline 9 & 150.7 & 145.6 & \\
\hline 10 & 116.6 & 115.7 & \\
\hline $1^{\prime}$ & 119.2 & 122.6 & 112.2 \\
\hline $2^{\prime}$ & 160.0 & 161.9 & 165.4 \\
\hline $3^{\prime}$ & 98.8 & 100.5 & 112.9 \\
\hline $4^{\prime}$ & 162.0 & 160.4 & 165.6 \\
\hline $5^{\prime}$ & 108.9 & 110.4 & 109.7 \\
\hline $6^{\prime}$ & 126.1 & 126.0 & 133.2 \\
\hline $1^{\prime \prime}$ & 105.1 & 102.6 & 75.6 \\
\hline $2^{\prime \prime}$ & 75.8 & 75.0 & 72.9 \\
\hline $3^{\prime \prime}$ & 78.4 & 78.2 & 80.2 \\
\hline $4^{\prime \prime}$ & 71.5 & 71.5 & 71.8 \\
\hline $5^{\prime \prime}$ & 77.9 & 78.0 & 82.7 \\
\hline $6^{\prime \prime}$ & 62.7 & 62.6 & 62.8 \\
\hline$-\mathrm{OCH}_{3}$ & 57.1 & 57.8 & \\
\hline$\alpha$ & & & 74.4 \\
\hline$\beta$ & & & 42.2 \\
\hline$>\mathrm{C}=\mathrm{O}$ & & & 205.7 \\
\hline
\end{tabular}

$\left(\mathrm{CD}_{3} \mathrm{OD}, 100 \mathrm{MHz}\right) \delta: 7.24(1 \mathrm{H}, \mathrm{d}, J=9 \mathrm{~Hz}, \mathrm{H}-5), 7.09(1 \mathrm{H}, \mathrm{d}, J=8 \mathrm{~Hz}, \mathrm{H}-$ $\left.6^{\prime}\right), 6.78(1 \mathrm{H}, \mathrm{d}, J=9 \mathrm{~Hz}, \mathrm{H}-6), 6.33\left(1 \mathrm{H}, \mathrm{dd}, J=8,2 \mathrm{~Hz}, \mathrm{H}-5^{\prime}\right), 6.24(1 \mathrm{H}, \mathrm{d}$, $\left.J=2 \mathrm{~Hz}, \mathrm{H}-3^{\prime}\right), 5.51(1 \mathrm{H}, \mathrm{d}, J=7 \mathrm{~Hz}, \mathrm{H}-4), 4.90\left(1 \mathrm{H}, \mathrm{d}, J=8 \mathrm{~Hz}, \mathrm{H}-1^{\prime \prime}\right), 4.31$ $(1 \mathrm{H}, \mathrm{dd}, J=10,3 \mathrm{~Hz}, \mathrm{H}-2 \mathrm{a}), 3.87\left(3 \mathrm{H}, \mathrm{s},-\mathrm{OCH}_{3}\right), 3.76(1 \mathrm{H}, \mathrm{dd}, J=12,3 \mathrm{~Hz}$, H-6"a), 3.65 (1H, dd, $J=12,5 \mathrm{~Hz}, \mathrm{H}-6 " \mathrm{~b}), 3.61$ (1H, dd, $J=10,10 \mathrm{~Hz}, \mathrm{H}-2 \mathrm{~b})$, $3.58(1 \mathrm{H}$, ddd, $J=10,7,3 \mathrm{~Hz}, \mathrm{H}-3), 3.47\left(1 \mathrm{H}, \mathrm{dd}, J=9,8 \mathrm{~Hz}, \mathrm{H}-2^{\prime \prime}\right), 3.42$ $\left(1 \mathrm{H}, \mathrm{dd}, J=10,9 \mathrm{~Hz}, \mathrm{H}-4^{\prime \prime}\right), 3.40\left(1 \mathrm{H}, \mathrm{dd}, J=10,9 \mathrm{~Hz}, \mathrm{H}-3^{\prime \prime}\right), 3.19(1 \mathrm{H}, \mathrm{m}$, $\left.\mathrm{H}-5^{\prime \prime}\right) ;{ }^{13} \mathrm{C}-\mathrm{NMR}\left(\mathrm{CD}_{3} \mathrm{OD}, 100 \mathrm{MHz}\right)$ : Table 2; CD $\Delta \varepsilon(\mathrm{nm}):+4.90(285)$, -13.1 (234), $-17.2(213)\left(c=4.29 \times 10^{-5} \mathrm{M}\right)$; HR-ESI-MS (positive-ion mode) $m / z$ : $471.1264[\mathrm{M}+\mathrm{Na}]^{+}\left(\mathrm{Calcd}\right.$ for $\left.\mathrm{C}_{22} \mathrm{H}_{24} \mathrm{O}_{10} \mathrm{Na}: 471.1261\right)$.

Compound 5: Amorphous powder; $[\alpha]_{\mathrm{D}}^{25}-94.1^{\circ}(c=0.19, \mathrm{MeOH})$; IR $v_{\max }$ (film) $\mathrm{cm}^{-1}: 3360,2937,1620,1491,1269,1100,1070,707$; UV $\lambda_{\max }$ $(\mathrm{MeOH}) \mathrm{nm}(\log \varepsilon): 280$ (3.61), 233sh (3.92), 213 (4.25); ${ }^{1} \mathrm{H}-\mathrm{NMR}$ $\left(\mathrm{CD}_{3} \mathrm{OD}, 100 \mathrm{MHz}\right) \delta$ : $7.18\left(1 \mathrm{H}, \mathrm{d}, J=8 \mathrm{~Hz}, \mathrm{H}-6^{\prime}\right), 6.95(1 \mathrm{H}, \mathrm{d}, J=9 \mathrm{~Hz}, \mathrm{H}-$ 5), $6.69(1 \mathrm{H}, \mathrm{d}, J=9 \mathrm{~Hz}, \mathrm{H}-6), 6.64\left(1 \mathrm{H}, \mathrm{dd}, J=8,2 \mathrm{~Hz}, \mathrm{H}-5^{\prime}\right), 6.57(1 \mathrm{H}, \mathrm{d}$, $\left.J=2 \mathrm{~Hz}, \mathrm{H}-3^{\prime}\right), 5.53(1 \mathrm{H}, \mathrm{d}, J=7 \mathrm{~Hz}, \mathrm{H}-4), 4.84\left(1 \mathrm{H}, \mathrm{d}, J=8 \mathrm{~Hz}, \mathrm{H}-1^{\prime \prime}\right), 4.30$ $(1 \mathrm{H}, \mathrm{dd}, J=10,3 \mathrm{~Hz}, \mathrm{H}-2 \mathrm{a}), 3.84\left(3 \mathrm{H}, \mathrm{s},-\mathrm{OCH}_{3}\right), 3.87(1 \mathrm{H}, \mathrm{dd}, J=12,2 \mathrm{~Hz}$, H-6"a), 3.68 (1H, dd, $\left.J=12,5 \mathrm{~Hz}, \mathrm{H}-6^{\prime \prime} \mathrm{b}\right), 3.61(1 \mathrm{H}, \mathrm{dd}, J=10,10 \mathrm{~Hz}, \mathrm{H}-2 \mathrm{~b})$, $3.58(1 \mathrm{H}, \mathrm{dd}, J=10,7 \mathrm{~Hz}, \mathrm{H}-3), 3.44\left(1 \mathrm{H}, \mathrm{dd}, J=9,8 \mathrm{~Hz}, \mathrm{H}-2^{\prime \prime}\right), 3.39(1 \mathrm{H}$, dd, $\left.J=9,10 \mathrm{~Hz}, \mathrm{H}-4^{\prime \prime}\right), 3.45\left(1 \mathrm{H}, \mathrm{dd}, J=9,9 \mathrm{~Hz}, \mathrm{H}-3^{\prime \prime}\right), 3.40\left(1 \mathrm{H}, \mathrm{m}, \mathrm{H}-5^{\prime \prime}\right)$; ${ }^{13} \mathrm{C}$-NMR $\left(\mathrm{CD}_{3} \mathrm{OD}, 100 \mathrm{MHz}\right)$ : Table 2; CD $\Delta \varepsilon(\mathrm{nm}):+2.96(285),-13.9$ (233), - 11.1 (212) $\left(c=4.17 \times 10^{-5} \mathrm{M}\right)$; HR-ESI-MS (positive-ion mode) $\mathrm{m} / \mathrm{z}$ : $471.1254[\mathrm{M}+\mathrm{Na}]^{+}\left(\right.$Calcd for $\left.\mathrm{C}_{22} \mathrm{H}_{24} \mathrm{O}_{10} \mathrm{Na}: 471.1261\right)$.

Compound 6: Amorphous powder; $[\alpha]_{\mathrm{D}}^{21}+61.5^{\circ}(c=0.27, \mathrm{MeOH})$; IR $v_{\max }\left(\right.$ film) $\mathrm{cm}^{-1}: 3367,2928,16180,1514,1444,1396,1249,1077,1028$, 711; UV $\lambda_{\max }(\mathrm{MeOH}) \mathrm{nm}(\log \varepsilon): 319 \mathrm{sh}$ (3.72), 283 (3.97), 239sh (3.86), 220 (4.17); ${ }^{1} \mathrm{H}-\mathrm{NMR}\left(\mathrm{CD}_{3} \mathrm{OD}, 100 \mathrm{MHz}\right) \delta: 7.71\left(1 \mathrm{H}, \mathrm{d}, J=9 \mathrm{~Hz}, \mathrm{H}-6^{\prime}\right)$ $7.01(2 \mathrm{H}, \mathrm{d}, J=8 \mathrm{~Hz}, \mathrm{H}-2,6), 6.67(2 \mathrm{H}, \mathrm{d}, J=8 \mathrm{~Hz}, \mathrm{H}-3,5), 6.41(1 \mathrm{H}, \mathrm{d}$, $\left.J=9 \mathrm{~Hz}, \mathrm{H}-5^{\prime}\right), 5.17(1 \mathrm{H}, \mathrm{dd}, J=7,5 \mathrm{~Hz}, \mathrm{H}-\alpha), 4.94\left(1 \mathrm{H}, \mathrm{d}, J=10 \mathrm{~Hz}, \mathrm{H}-1^{\prime \prime}\right)$, $4.05\left(1 \mathrm{H}, \mathrm{dd}, J=10,10 \mathrm{~Hz}, \mathrm{H}-2^{\prime \prime}\right), 3.86\left(1 \mathrm{H}, \mathrm{dd}, J=12,2 \mathrm{~Hz}, \mathrm{H}-6^{\prime \prime} \mathrm{a}\right), 3.74$ $\left(1 \mathrm{H}, \mathrm{dd}, J=12,5 \mathrm{~Hz}, \mathrm{H}-6^{\prime \prime} \mathrm{b}\right), 3.49\left(1 \mathrm{H}, \mathrm{dd}, J=10,10 \mathrm{~Hz}, \mathrm{H}-4^{\prime \prime}\right), 3.48(1 \mathrm{H}$, dd, $\left.J=10,10 \mathrm{~Hz}, \mathrm{H}-3^{\prime \prime}\right), 3.42\left(1 \mathrm{H}, \mathrm{m}, \mathrm{H}-5^{\prime \prime}\right), 3.04(1 \mathrm{H}, \mathrm{dd}, J=14,5 \mathrm{~Hz}, \mathrm{H}-$ $\beta$ a), $2.86(1 \mathrm{H}, \mathrm{dd}, J=14,7 \mathrm{~Hz}, \mathrm{H}-\beta \mathrm{b}) ;{ }^{13} \mathrm{C}-\mathrm{NMR}\left(\mathrm{CD}_{3} \mathrm{OD}, 100 \mathrm{MHz}\right)$ : Table 2; CD $\Delta \varepsilon(\mathrm{nm}):+32.0(325),+17.9(293),-5.80(254),[\theta] \mathrm{nm}+105600$ $(325),+59070(293),-19140(254)\left(c=3.00 \times 10^{-5} \mathrm{M}\right)$; HR-ESI-MS (positive-ion mode) $m / z$ : $459.1236[\mathrm{M}+\mathrm{Na}]^{+}$(Calcd for $\mathrm{C}_{21} \mathrm{H}_{24} \mathrm{O}_{10} \mathrm{Na}$ : 459.1261).

Enzymatic Hydrolysis of Crotalionoside A (1) Crotalionoside A (1) (4.2 mg) in $2 \mathrm{ml}$ of $\mathrm{H}_{2} \mathrm{O}$ was hydrolyzed with emulsin $(5.2 \mathrm{mg})$ and crude hesperidinase $(5.0 \mathrm{mg})$ for $24 \mathrm{~h}$ at $37^{\circ} \mathrm{C}$. The reaction mixture was evapo- 
rated to dryness, and then the methanolic solution was adsorbed on silica gel and subjected to silica gel $\mathrm{CC}(20 \mathrm{~g}, \Phi=22 \mathrm{~mm}, L=11 \mathrm{~cm})$ with $\mathrm{CHCl}_{3}$ $(100 \mathrm{ml})$ and $\mathrm{CHCl}_{3}-\mathrm{MeOH}(19: 1,100 \mathrm{ml}, 9: 1,100 \mathrm{ml}, 17: 3,100 \mathrm{ml}$, and $7: 3,300 \mathrm{ml}), 12 \mathrm{ml}$ fractions being collected. Crotalionol A (1a) (1.8 mg, $72 \%)$ and D-glucose $(1.6 \mathrm{mg}, 86 \%)$ were recovered in fractions $26-31$ and 36 42, respectively. Crotalionol A (1a): an amorphous powder, $[\alpha]_{\mathrm{D}}^{27}$ $-34.2^{\circ}(c=0.12, \mathrm{MeOH}) ;{ }^{1} \mathrm{H}-\mathrm{NMR}\left(\mathrm{CD}_{3} \mathrm{OD}, 400 \mathrm{MHz}\right) \delta: 5.35(1 \mathrm{H}, \mathrm{d}$, $J=6 \mathrm{~Hz}, \mathrm{H}-8), 4.27(1 \mathrm{H}, \mathrm{qd}, J=6,6 \mathrm{~Hz}, \mathrm{H}-9), 3.95(1 \mathrm{H}, \mathrm{ddd}, J=12,9,5 \mathrm{~Hz}$, H-3), $2.99(1 \mathrm{H}, \mathrm{d}, J=9 \mathrm{~Hz}, \mathrm{H}-4), 1.82(1 \mathrm{H}, \mathrm{dd}, J=12,5 \mathrm{~Hz}, \mathrm{H}-2 \mathrm{a}), 1.36(3 \mathrm{H}$ $\left.\mathrm{s}, \mathrm{H}_{3}-13\right), 1.34(1 \mathrm{H}, \mathrm{dd}, J=12,12 \mathrm{~Hz}, \mathrm{H}-2 \mathrm{~b}), 1.30\left(3 \mathrm{H}, \mathrm{s}, \mathrm{H}_{3}-11\right), 1.25(3 \mathrm{H}$, d, $\left.J=6 \mathrm{~Hz}, \mathrm{H}_{3}-10\right), 1.06\left(3 \mathrm{H}, \mathrm{s}, \mathrm{H}_{3}-12\right) ;{ }^{13} \mathrm{C}-\mathrm{NMR}\left(\mathrm{CD}_{3} \mathrm{OD}, 100 \mathrm{MHz}\right) \delta$ : 200.8 (C-7), 117.6 (C-6), 100.3 (C-8), 82.2 (C-4), 74.7 (C-5), 69.2 (C-3), 67.2 (C-9), 47.6 (C-2), 35.6 (C-1), 32.9 (C-12), 29.4 (C-11), 26.7 (C-13), 23.5 (C-10); HR-ESI-TOF-MS (positive-ion mode) $\mathrm{m} / \mathrm{z}: 265.1409$ $[\mathrm{M}+\mathrm{Na}]^{+}\left(\right.$Calcd for $\left.\mathrm{C}_{13} \mathrm{H}_{22} \mathrm{O}_{4} \mathrm{Na}, 265.1410\right)$. D-Glucose: $[\alpha]_{\mathrm{D}}^{27}+35.2^{\circ}$ ( $c=0.11, \mathrm{H}_{2} \mathrm{O}, 24 \mathrm{~h}$ after being dissolved in the solvent).

Preparation of Crotalionol A $(R)$ - and $(S)$-MTPA 3,9-Diesters $(1 b, 1 c)$ from 1a A solution of $1 \mathrm{a}(1.1 \mathrm{mg})$ in $1 \mathrm{ml}$ of dehydrated $\mathrm{CH}_{2} \mathrm{Cl}_{2}$ was reacted with $(R)$-MTPA $(66 \mathrm{mg})$ in the presence of EDC $(17 \mathrm{mg})$ and 4-DMAP $(12 \mathrm{mg})$, the mixture being occasionally stirred at $25^{\circ} \mathrm{C}$ for $6 \mathrm{~h}$. After the addition of $1 \mathrm{ml}$ of $\mathrm{CH}_{2} \mathrm{Cl}_{2}$, the solution was washed with $\mathrm{H}_{2} \mathrm{O}(1 \mathrm{ml}), 5 \% \mathrm{HCl}$ $(1 \mathrm{ml}), \mathrm{NaHCO}_{3}$-saturated $\mathrm{H}_{2} \mathrm{O}$, and then brine $(1 \mathrm{ml})$, successively. The organic layer was dried over $\mathrm{Na}_{2} \mathrm{SO}_{4}$ and then evaporated under reduced pressure. The residue was purified by preparative TLC [silica gel $(0.25 \mathrm{~mm}$ thickness), being applied for $18 \mathrm{~cm}$, development with $\mathrm{CHCl}_{3}-\left(\mathrm{CH}_{3}\right)_{2} \mathrm{CO}$ (19:1) for $9 \mathrm{~cm}$, and then eluted with $\left.\mathrm{CHCl}_{3}-\mathrm{MeOH}(9: 1)\right]$ to furnish an ester, $\mathbf{1 b}(0.5 \mathrm{mg}, 29 \%)$. Through a similar procedure, $\mathbf{1 c}(1.0 \mathrm{mg}, 45 \%)$ was prepared from 1a $(0.8 \mathrm{mg})$ using $(S)$-MTPA $(46 \mathrm{mg})$, EDC $(17 \mathrm{mg})$, and 4 DMAP $(12 \mathrm{mg})$. Crotalionol A 3,9-di- $O-(R)$-MTPA ester (1b) of 1a: an amorphous powder; ${ }^{1} \mathrm{H}-\mathrm{NMR}\left(\mathrm{CDCl}_{3}, 400 \mathrm{MHz}\right) \delta: 7.46-7.59(4 \mathrm{H}, \mathrm{m}$, aromatic protons $), 7.34-7.43(6 \mathrm{H}, \mathrm{m}$, aromatic protons $), 5.55(1 \mathrm{H}, \mathrm{qd}, J=6$, $6 \mathrm{~Hz}, \mathrm{H}-9), 5.46$ (1H, ddd, $J=12,9,5 \mathrm{~Hz}, \mathrm{H}-3), 5.41(1 \mathrm{H}, \mathrm{dd}, J=6,1 \mathrm{~Hz}, \mathrm{H}-$ 8), $3.59\left(3 \mathrm{H}, \mathrm{s},-\mathrm{OCH}_{3}\right), 3.54\left(3 \mathrm{H}, \mathrm{s},-\mathrm{OCH}_{3}\right), 3.29(1 \mathrm{H}, \mathrm{d}, J=9 \mathrm{~Hz}, \mathrm{H}-4)$, $1.96(1 \mathrm{H}, \mathrm{dd}, J=12,5 \mathrm{~Hz}, \mathrm{H}-2 \mathrm{a}), 1.45(1 \mathrm{H}, \mathrm{dd}, J=12,12 \mathrm{~Hz}, \mathrm{H}-2 \mathrm{~b}), 1.42$ $\left(3 \mathrm{H}, \mathrm{d}, J=6 \mathrm{~Hz}, \mathrm{H}_{3}-10\right), 1.37\left(3 \mathrm{H}, \mathrm{s}, \mathrm{H}_{3}-11\right), 1.34\left(3 \mathrm{H}, \mathrm{s}, \mathrm{H}_{3}-13\right), 0.96(3 \mathrm{H}$, $\mathrm{s}, \mathrm{H}_{3}-12$ ); HR-ESI-TOF-MS (positive-ion mode) $\mathrm{m} / \mathrm{z}: 697.2209[\mathrm{M}+\mathrm{Na}]^{+}$ (Calcd for $\mathrm{C}_{33} \mathrm{H}_{36} \mathrm{O}_{8} \mathrm{~F}_{6} \mathrm{Na}$, 697.2206). Crotalionol A 3,9-di-O-(S)-MTPA ester (1c) of 1a: an amorphous powder, ${ }^{1} \mathrm{H}-\mathrm{NMR}\left(\mathrm{CDCl}_{3}, 400 \mathrm{MHz}\right) \delta$ : $7.48-7.67(4 \mathrm{H}, \mathrm{m}$, aromatic protons $), 7.34-7.42(6 \mathrm{H}, \mathrm{m}$, aromatic protons), $5.53(1 \mathrm{H}, \mathrm{qd}, J=6,6 \mathrm{~Hz}, \mathrm{H}-9), 5.48(1 \mathrm{H}, \mathrm{d}, J=6 \mathrm{~Hz}, \mathrm{H}-8), 5.47(1 \mathrm{H}$, ddd, $J=12,9,5 \mathrm{~Hz}, \mathrm{H}-3), 3.60\left(3 \mathrm{H}, \mathrm{q}, J=1 \mathrm{~Hz},-\mathrm{OCH}_{3}\right), 3.51(3 \mathrm{H}, \mathrm{q}$, $\left.J=1 \mathrm{~Hz},-\mathrm{OCH}_{3}\right), 3.34(1 \mathrm{H}, \mathrm{d}, J=9 \mathrm{~Hz}, \mathrm{H}-4), 1.90(1 \mathrm{H}, \mathrm{dd}, J=12,5 \mathrm{~Hz}, \mathrm{H}-$ 2a), $1.41(1 \mathrm{H}, \mathrm{dd}, J=12,12 \mathrm{~Hz}, \mathrm{H}-2 \mathrm{~b}), 1.38\left(3 \mathrm{H}, \mathrm{s}, \mathrm{H}_{3}-11\right), 1.36(3 \mathrm{H}, \mathrm{d}$, $\left.J=6 \mathrm{~Hz}, \mathrm{H}_{3}-10\right), 1.36\left(3 \mathrm{H}, \mathrm{s}, \mathrm{H}_{3}-13\right), 1.01\left(3 \mathrm{H}, \mathrm{s}, \mathrm{H}_{3}-12\right)$; HR-ESI-TOF-MS (positive-ion mode) $\mathrm{m} / \mathrm{z}$ : $697.2204[\mathrm{M}+\mathrm{Na}]^{+}$(Calcd for $\mathrm{C}_{33} \mathrm{H}_{36} \mathrm{O}_{8} \mathrm{~F}_{6} \mathrm{Na}$, 697.2206).

Enzymatic Hydrolysis of Crotalionoside B (2) Crotalionoside B (2) $(0.9 \mathrm{mg})$ was similarly hydrolyzed with emulsin $(1.5 \mathrm{mg})$ and crude hesperidinase $(1.5 \mathrm{mg})$. The reaction mixture was evaporated to dryness, and then the methanolic solution was adsorbed on silica gel and subjected to silica gel CC $(7 \mathrm{~g}, \Phi=10 \mathrm{~mm}, L=17 \mathrm{~cm})$ with $\mathrm{CHCl}_{3}(50 \mathrm{ml})$ and $\mathrm{CHCl}_{3}$ $\mathrm{MeOH}(19: 1,50 \mathrm{ml}, 9: 1,50 \mathrm{ml}, 17: 3,50 \mathrm{ml}$, and $7: 3,150 \mathrm{ml}), 5 \mathrm{ml}$ fractions being collected. Crotalionol B (2a) $(0.4 \mathrm{mg}, 74 \%)$ and D-glucose $(0.2 \mathrm{mg}, 50 \%)$ were recovered in fractions $28-34$ and $45-53$, respectively. Crotalionol B (2a): amorphous powder; $[\alpha]_{\mathrm{D}}^{25}+3.77^{\circ}(c=0.038, \mathrm{MeOH})$; ${ }^{1} \mathrm{H}-\mathrm{NMR}\left(\mathrm{CD}_{3} \mathrm{OD}, 400 \mathrm{MHz}\right) \delta: 5.35(1 \mathrm{H}, \mathrm{d}, J=6 \mathrm{~Hz}, \mathrm{H}-8), 4.28(1 \mathrm{H}, \mathrm{qd}$, $J=6,6 \mathrm{~Hz}, \mathrm{H}-9), 3.94$ (1H, ddd, $J=12,95 \mathrm{~Hz}, \mathrm{H}-3), 3.00(1 \mathrm{H}, \mathrm{d}, J=9 \mathrm{~Hz}$, $\mathrm{H}-4), 1.82(1 \mathrm{H}, \mathrm{dd}, J=12,5 \mathrm{~Hz}, \mathrm{H}-2 \mathrm{a}), 1.36\left(3 \mathrm{H}, \mathrm{s}, \mathrm{H}_{3}-13\right), 1.35(1 \mathrm{H}, \mathrm{dd}$, $J=12,12 \mathrm{~Hz}, \mathrm{H}-2 \mathrm{~b}), 1.30$ (3H, s, $\left.\mathrm{H}_{3}-11\right), 1.25$ (3H, d, $\left.J=6 \mathrm{~Hz}, \mathrm{H}_{3}-10\right), 1.06$ $\left(3 \mathrm{H}, \mathrm{s}, \mathrm{H}_{3}-12\right) ;{ }^{13} \mathrm{C}-\mathrm{NMR}\left(\mathrm{CD}_{3} \mathrm{OD}, 100 \mathrm{MHz}\right) \delta: 200.7(\mathrm{C}-7), 117.6(\mathrm{C}-6)$, 100.4 (C-8), 82.2 (C-4), 74.7 (C-5), 69.2 (C-3), 67.2 (C-9), 48.0 (C-2), 35.7 (C-1), 32.7 (C-12), 29.4 (C-11), 26.8 (C-13), 23.5 (C-10); HR-ESI-TOF-MS (positive-ion mode) $m / z$ : $265.1408[\mathrm{M}+\mathrm{Na}]^{+}\left(\mathrm{Calcd}\right.$ for $\mathrm{C}_{13} \mathrm{H}_{22} \mathrm{O}_{4} \mathrm{Na}$, 265.1410).

Preparation of Crotalionol B $(R)$ - and (S)-MTPA 3,9-Diesters (2b, 2c) from $2 \mathbf{a}$ From $\mathbf{2 a}(0.2 \mathrm{mg}$ each $), \mathbf{2 b}(0.2 \mathrm{mg}, 36 \%)$ and $\mathbf{2 c}(0.3 \mathrm{mg}, 54 \%)$ were prepared with the respective amounts of $(R)$ - and $(S)$-MTPA (51, $41 \mathrm{mg})$, EDC $(13,15 \mathrm{mg})$, and 4-DMAP (10, $18 \mathrm{mg})$. Crotalionol B 3,9-di$O$-(R)-MTPA ester (2b): an amorphous powder, ${ }^{1} \mathrm{H}-\mathrm{NMR}\left(\mathrm{CDCl}_{3}, 400 \mathrm{MHz}\right)$ $\delta: 7.49-7.58(4 \mathrm{H}, \mathrm{m}$, aromatic protons $), 7.36-7.43(6 \mathrm{H}, \mathrm{m}$, aromatic protons), $5.58(1 \mathrm{H}, \mathrm{qd}, J=6,6 \mathrm{~Hz}, \mathrm{H}-9), 5.52(1 \mathrm{H}, \mathrm{d}, J=6 \mathrm{~Hz}, \mathrm{H}-8), 5.46(1 \mathrm{H}$, ddd, $J=12,9,5 \mathrm{~Hz}, \mathrm{H}-3), 3.58\left(3 \mathrm{H}, \mathrm{q}, J=1 \mathrm{~Hz},-\mathrm{OCH}_{3}\right), 3.51(3 \mathrm{H}, \mathrm{q}$, $\left.J=1 \mathrm{~Hz},-\mathrm{OCH}_{3}\right), 3.28(1 \mathrm{H}, \mathrm{d}, J=9 \mathrm{~Hz}, \mathrm{H}-4), 2.00(1 \mathrm{H}, \mathrm{dd}, J=12,5 \mathrm{~Hz}, \mathrm{H}-$ 2a), $1.39\left(3 \mathrm{H}, \mathrm{s}, \mathrm{H}_{3}-11\right), 1.36\left(3 \mathrm{H}, \mathrm{d}, J=6 \mathrm{~Hz}, \mathrm{H}_{3}-10\right), 1.32\left(3 \mathrm{H}, \mathrm{s}, \mathrm{H}_{3}-13\right)$, $1.06\left(3 \mathrm{H}, \mathrm{s}, \mathrm{H}_{3}-12\right), \mathrm{H}-2 \mathrm{~b}$ could not be assigned, due to overlapping signals; HR-ESI-TOF-MS (positive-ion mode) $\mathrm{m} / \mathrm{z}: 697.2213[\mathrm{M}+\mathrm{Na}]^{+}$(Calcd for $\mathrm{C}_{33} \mathrm{H}_{36} \mathrm{O}_{8} \mathrm{~F}_{6} \mathrm{Na}$, 697.2206). Crotalionol B 3,9-di-O-(S)-MTPA ester (2c): an amorphous powder, ${ }^{1} \mathrm{H}-\mathrm{NMR}\left(\mathrm{CDCl}_{3}, 400 \mathrm{MHz}\right) \delta: 7.46-7.62(4 \mathrm{H}, \mathrm{m}$, aromatic protons $), 7.33-7.43(6 \mathrm{H}, \mathrm{m}$, aromatic protons $), 5.56(1 \mathrm{H}, \mathrm{qd}, J=6$, $6 \mathrm{~Hz}, \mathrm{H}-9), 5.43$ (1H, d, $J=6 \mathrm{~Hz}, \mathrm{H}-8), 5.43$ (1H, ddd, $J=12,9,5 \mathrm{~Hz}, \mathrm{H}-3)$, $3.61\left(3 \mathrm{H}, \mathrm{q}, J=1 \mathrm{~Hz},-\mathrm{OCH}_{3}\right), 3.56\left(3 \mathrm{H}, \mathrm{q}, J=1 \mathrm{~Hz},-\mathrm{OCH}_{3}\right), 3.16(1 \mathrm{H}, \mathrm{d}$, $J=9 \mathrm{~Hz}, \mathrm{H}-4), 1.88(1 \mathrm{H}, \mathrm{dd}, J=12,5 \mathrm{~Hz}, \mathrm{H}-2 \mathrm{a}), 1.42\left(3 \mathrm{H}, \mathrm{s}, \mathrm{H}_{3}-11\right), 1.42$ $\left(3 \mathrm{H}, \mathrm{d}, J=6 \mathrm{~Hz}, \mathrm{H}_{3}-10\right), 1.36\left(3 \mathrm{H}, \mathrm{s}, \mathrm{H}_{3}-13\right), 1.02\left(3 \mathrm{H}, \mathrm{s}, \mathrm{H}_{3}-12\right), \mathrm{H}-2 \mathrm{~b}$ could not be assigned, due to overlapping signals; HR-ESI-TOF-MS (positive-ion mode) $m / z$ : $697.2204[\mathrm{M}+\mathrm{Na}]^{+}\left(\right.$Calcd for $\mathrm{C}_{33} \mathrm{H}_{36} \mathrm{O}_{8} \mathrm{~F}_{6} \mathrm{Na}, 697.2206$ ).

$\mathrm{NaBH}_{4}$ Reduction of Citrosides A (10) and B (11) to the Corresponding Alcohols (10a, 10b) To a solution of citroside A (10) $(10 \mathrm{mg})$ in $0.5 \mathrm{ml}$ of $\mathrm{MeOH}$ was added $10 \mathrm{mg}$ of $\mathrm{CeCl}_{3} \cdot 7 \mathrm{H}_{2} \mathrm{O}$ and then $2 \mathrm{mg}$ of $\mathrm{NaBH}_{4}$, the reaction mixture being stirred for $5 \mathrm{~min}$ at $25^{\circ} \mathrm{C}$. Excess $\mathrm{NaBH}_{4}$ was quenched by the addition of $100 \mathrm{ml}$ of $\left(\mathrm{CH}_{3}\right)_{2} \mathrm{CO}$ and then the reaction mixture was evaporated and purified by preparative TLC (developed with $\mathrm{CHCl}_{3}$ $\mathrm{MeOH}-\mathrm{H}_{2} \mathrm{O}, 15: 6: 1$, and then eluted with $\left.\mathrm{CHCl}_{3}-\mathrm{MeOH}, 1: 1\right)$ to afford $1.7 \mathrm{mg}$ of $\mathbf{1 0 a}$. Citroside B (11) $(1.5 \mathrm{mg})$ was similarly reduced to give $0.5 \mathrm{mg}$ of 11a. 10a: CD $\Delta \varepsilon(\mathrm{nm}):+2.32(226)\left(c=4.90 \times 10^{-5} \mathrm{M}, \mathrm{MeOH}\right)$. 11a: CD $\Delta \varepsilon(\mathrm{nm}):+1.29(225)\left(c=5.15 \times 10^{-5} \mathrm{M}, \mathrm{MeOH}\right)$

HPLC Separation of 10a and 11a Compound 10a was separated by HPLC (MeOH- $\left.\mathrm{H}_{2} \mathrm{O}, 2: 3\right)$ to give $0.4 \mathrm{mg}$ of $\mathbf{1 0 b}$ and $0.2 \mathrm{mg}$ of $\mathbf{1 0 c}$ from the peaks at $11 \mathrm{~min}$ and $12 \mathrm{~min}$, respectively. Compound 11a was similarly separated by HPLC to give $50 \mu \mathrm{g}$ of $11 \mathbf{b}$ and $50 \mu \mathrm{g}$ of $11 \mathrm{c}$ from the peaks at $20 \mathrm{~min}$ and $23 \mathrm{~min}$, respectively. 10b: ${ }^{1} \mathrm{H}-\mathrm{NMR}\left(\mathrm{CD}_{3} \mathrm{OD}, 400 \mathrm{MHz}\right) \delta: 5.33$ $(1 \mathrm{H}, \mathrm{d}, J=6 \mathrm{~Hz}, \mathrm{H}-8), 4.50\left(1 \mathrm{H}, \mathrm{d}, J=8 \mathrm{~Hz}, \mathrm{H}-1^{\prime}\right), 4.28$ (2H, overlapped, H$3,9), 3.79$ (1H, dd, $\left.J=12,3 \mathrm{~Hz}, \mathrm{H}-6^{\prime} \mathrm{a}\right), 3.64$ (1H, dd, $\left.J=12,5 \mathrm{~Hz}, \mathrm{H}-6^{\prime} \mathrm{b}\right)$, $3.18-3.36\left(3 \mathrm{H}, \mathrm{m}, \mathrm{H}-3^{\prime}, 4^{\prime}, 5^{\prime}\right), 3.12\left(1 \mathrm{H}, \mathrm{dd}, J=9,8 \mathrm{~Hz}, \mathrm{H}-2^{\prime}\right), 2.41(1 \mathrm{H}$, ddd, $J=13,4,2 \mathrm{~Hz}, \mathrm{H}-4 \mathrm{a}), 1.84$ (1H, ddd, $J=13,4,2 \mathrm{~Hz}, \mathrm{H}-2 \mathrm{a}), 1.41$ (3H, s, $\left.\mathrm{H}_{3}-13\right), 1.29\left(3 \mathrm{H}, \mathrm{s}, \mathrm{H}_{3}-12\right), 1.26\left(3 \mathrm{H}, \mathrm{d}, J=6 \mathrm{~Hz}, \mathrm{H}_{3}-10\right), 1.09\left(3 \mathrm{H}, \mathrm{s}, \mathrm{H}_{3}-\right.$ $11), \mathrm{H}-2 \mathrm{~b}$ and $4 \mathrm{~b}$ could not be assigned, due to overlapping signals; CD $\Delta \varepsilon$ $(\mathrm{nm}):+1.20(226)\left(c=5.15 \times 10^{-5} \mathrm{M}, \mathrm{MeOH}\right)$; HR-ESI-TOF-MS (positiveion mode) $m / z: 411.1985[\mathrm{M}+\mathrm{Na}]^{+}$(Calcd for $\left.\mathrm{C}_{19} \mathrm{H}_{32} \mathrm{O}_{8} \mathrm{Na}, 411.1989\right)$. 10c: ${ }^{1} \mathrm{H}-\mathrm{NMR}\left(\mathrm{CD}_{3} \mathrm{OD}, 400 \mathrm{MHz}\right) \delta: 5.32(1 \mathrm{H}, \mathrm{d}, J=6 \mathrm{~Hz}, \mathrm{H}-8), 4.50(1 \mathrm{H}, \mathrm{d}$, $\left.J=8 \mathrm{~Hz}, \mathrm{H}-1^{\prime}\right), 4.27$ (2H, overlapped, H-3, 9), $3.79(1 \mathrm{H}, \mathrm{dd}, J=12,3 \mathrm{~Hz}, \mathrm{H}-$ $\left.6^{\prime} \mathrm{a}\right), 3.64$ ( $\left.1 \mathrm{H}, \mathrm{dd}, J=12,5 \mathrm{~Hz}, \mathrm{H}-6^{\prime} \mathrm{b}\right), 3.18-3.36\left(3 \mathrm{H}, \mathrm{m}, \mathrm{H}-3^{\prime}, 4^{\prime}, 5^{\prime}\right)$, $3.12\left(1 \mathrm{H}, \mathrm{dd}, J=9,8 \mathrm{~Hz}, \mathrm{H}-2^{\prime}\right), 2.41(1 \mathrm{H}, \mathrm{ddd}, J=13,4,2 \mathrm{~Hz}, \mathrm{H}-4 \mathrm{a}), 1.84$ $(1 \mathrm{H}, J=13,4,2 \mathrm{~Hz}, \mathrm{H}-2 \mathrm{a}), 1.42\left(3 \mathrm{H}, \mathrm{s}, \mathrm{H}_{3}-13\right), 1.29\left(3 \mathrm{H}, \mathrm{s}, \mathrm{H}_{3}-12\right), 1.26$ $\left(3 \mathrm{H}, \mathrm{d}, J=6 \mathrm{~Hz}, \mathrm{H}_{3}-10\right), 1.08\left(3 \mathrm{H}, \mathrm{s}, \mathrm{H}_{3}-11\right), \mathrm{H}-2 \mathrm{~b}$ and $4 \mathrm{~b}$ could not be assigned, due to overlapping signals; CD $\Delta \varepsilon(\mathrm{nm}):+1.65(226)(c=5.15 \times$ $10^{-5} \mathrm{M}, \mathrm{MeOH}$ ); HR-ESI-TOF-MS (positive-ion mode) $\mathrm{m} / \mathrm{z}: 411.1983$ $[\mathrm{M}+\mathrm{Na}]^{+}$(Calcd for $\left.\mathrm{C}_{19} \mathrm{H}_{32} \mathrm{O}_{8} \mathrm{Na}, 411.1989\right)$. 11b: ${ }^{1} \mathrm{H}-\mathrm{NMR}\left(\mathrm{CD}_{3} \mathrm{OD}\right.$, $400 \mathrm{MHz}) \delta: 5.43(1 \mathrm{H}, \mathrm{d}, J=6 \mathrm{~Hz}, \mathrm{H}-8), 4.53\left(1 \mathrm{H}, \mathrm{d}, J=8 \mathrm{~Hz}, \mathrm{H}-1^{\prime}\right), 4.51$ (1H, overlapped with HDO signal, H-9), $4.30(1 \mathrm{H}, \mathrm{m}, \mathrm{H}-3), 3.80(1 \mathrm{H}, \mathrm{dd}$, $\left.J=12,2 \mathrm{~Hz}, \mathrm{H}-6^{\prime} \mathrm{a}\right), 3.65$ (1H, dd, $\left.J=12,5 \mathrm{~Hz}, \mathrm{H}-6^{\prime} \mathrm{b}\right), 3.12-3.36$ (4H, m, H-2', 3', 4', 5'), 2.41 (1H, m, H-4a), 1.38 (1H, m, H-2a), $1.38\left(3 \mathrm{H}, \mathrm{s}, \mathrm{H}_{3}\right.$ 13), $1.33\left(3 \mathrm{H}, \mathrm{d}, J=6 \mathrm{~Hz}, \mathrm{H}_{3}-10\right), 1.30\left(3 \mathrm{H}, \mathrm{s}, \mathrm{H}_{3}-12\right), 1.08\left(3 \mathrm{H}, \mathrm{s}, \mathrm{H}_{3}-11\right)$, $\mathrm{H}-2 \mathrm{~b}$ and $4 \mathrm{~b}$ could not be assigned, due to overlapping signals; HRESI-TOF-MS (positive-ion mode) $\mathrm{m} / \mathrm{z}: 411.1991{\mathrm{[M}+\mathrm{Na}]^{+}}$(Calcd for $\left.\mathrm{C}_{19} \mathrm{H}_{32} \mathrm{O}_{8} \mathrm{Na}, 411.1989\right)$. 11c: ${ }^{1} \mathrm{H}-\mathrm{NMR}\left(\mathrm{CD}_{3} \mathrm{OD}, 400 \mathrm{MHz}\right) \delta: 5.40(1 \mathrm{H}, \mathrm{d}$, $J=6 \mathrm{~Hz}, \mathrm{H}-8), 4.53\left(1 \mathrm{H}, \mathrm{d}, J=8 \mathrm{~Hz}, \mathrm{H}-1^{\prime}\right), 4.51$ (1H, overlapped with HDO signal, H-9), 4.30 (1H, m, H-3), 3.80 (1H, dd, $\left.J=12,2 \mathrm{~Hz}, \mathrm{H}-6^{\prime} \mathrm{a}\right), 3.65$ (1H, dd, $\left.J=12,5 \mathrm{~Hz}, \mathrm{H}-6^{\prime} \mathrm{b}\right), 3.12-3.36\left(4 \mathrm{H}, \mathrm{m}, \mathrm{H}-2^{\prime}, 3^{\prime}, 4^{\prime}, 5^{\prime}\right), 2.41(1 \mathrm{H}, \mathrm{m}$, H-4a), 1.83 (1H, m, H-2a), 1.40 (3H, s, $\left.\mathrm{H}_{3}-13\right), 1.31$ (3H, d, J=6 Hz, $\mathrm{H}_{3}-10$ ), $1.29\left(3 \mathrm{H}, \mathrm{s}, \mathrm{H}_{3}-12\right), 1.06\left(3 \mathrm{H}, \mathrm{s}, \mathrm{H}_{3}-11\right), \mathrm{H}-2 \mathrm{~b}$ and $4 \mathrm{~b}$ could not be assigned, due to overlapping signals; HR-ESI-TOF-MS (positive-ion mode) $m / z$ :

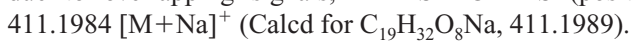

Enzymatic Hydrolysis of Crotalionoside C (3) Crotalionoside C (3) $(4.5 \mathrm{mg})$ was hydrolyzed with emulsin $(4.5 \mathrm{mg})$ and crude hesperidinase $(4.0 \mathrm{mg})$ at $37^{\circ} \mathrm{C}$ for $24 \mathrm{~h}$. The reaction mixture was evaporated to dryness, and then the methanolic solution was adsorbed on silica gel and subjected to silica gel CC $(25 \mathrm{~g}, \Phi=22 \mathrm{~mm}, L=13 \mathrm{~cm})$ with $\mathrm{CHCl}_{3}(100 \mathrm{ml})$ and $\mathrm{CHCl}_{3}-\mathrm{MeOH}(19: 1,100 \mathrm{ml}, 9: 1,100 \mathrm{ml}, 17: 3,100 \mathrm{ml}$, and $7: 3,300 \mathrm{ml})$, $5 \mathrm{ml}$ fractions being collected. Crotalionol C (3a) $(2.2 \mathrm{mg}, 86 \%)$ and glucose $(1.4 \mathrm{mg}, 67 \%)$ were recovered in fractions $21-24$ and fractions $49-55$, repectively. Crotalionol C (3a): Amorphous powder; $[\alpha]_{\mathrm{D}}^{24}-23.1^{\circ}(c=0.15$, $\mathrm{MeOH}) ;{ }^{1} \mathrm{H}-\mathrm{NMR}\left(\mathrm{CD}_{3} \mathrm{OD}, 400 \mathrm{MHz}\right) \delta: 5.74(1 \mathrm{H}, \mathrm{d}, J=16 \mathrm{~Hz}, \mathrm{H}-7), 5.70$ $(1 \mathrm{H}, \mathrm{dd}, J=16,5 \mathrm{~Hz}, \mathrm{H}-8), 4.32(1 \mathrm{H}$, br dd, $J=6,6 \mathrm{~Hz}, \mathrm{H}-3), 4.29(1 \mathrm{H}, \mathrm{qd}$, $J=6,5 \mathrm{~Hz}, \mathrm{H}-9), 1.95$ (1H, ddd, $J=12,6,2 \mathrm{~Hz}, \mathrm{H}-4 \mathrm{a}), 1.77$ (1H, ddd, $J=12$, 6, $2 \mathrm{~Hz}, \mathrm{H}-2 \mathrm{a}), 1.65$ (1H, d, $J=12 \mathrm{~Hz}, \mathrm{H}-4 \mathrm{~b}), 1.59$ (1H, d, $J=12 \mathrm{~Hz}, \mathrm{H}-2 \mathrm{~b})$, $1.40\left(3 \mathrm{H}, \mathrm{s}, \mathrm{H}_{3}-11\right), 1.24\left(3 \mathrm{H}, \mathrm{d}, J=6 \mathrm{~Hz}, \mathrm{H}_{3}-10\right), 1.17\left(3 \mathrm{H}, \mathrm{s}, \mathrm{H}_{3}-13\right), 0.86$ $\left(3 \mathrm{H}, \mathrm{s}, \mathrm{H}_{3}-12\right) ;{ }^{13} \mathrm{C}-\mathrm{NMR}\left(\mathrm{CD}_{3} \mathrm{OD}, 100 \mathrm{MHz}\right) \delta: 136.2(\mathrm{C}-8), 124.6(\mathrm{C}-7)$, 92.7 (C-6), 82.2 (C-5), 76.7 (C-3), 69.3 (C-9), 49.4 (C-2), 48.7 (C-4), 44.5 
(C-1), 32.7 (C-12), 31.4 (C-13), 25.9 (C-11), 24.0 (C-10); HR-ESI-TOF-MS (positive-ion mode) $m / z$ : $249.1463[\mathrm{M}+\mathrm{Na}]^{+}$(Calcd for $\mathrm{C}_{13} \mathrm{H}_{22} \mathrm{O}_{3} \mathrm{Na}$, 249.1461).

Preparation of Crotalionol C $(R)$ - and $(S)$-MTPA 9-Esters $(3 \mathrm{~b}, 3 \mathrm{c})$ from 3a From 3a (1.1 mg each), 3b $(1.3 \mathrm{mg}, 60 \%)$ and $\mathbf{3 c}(1.2 \mathrm{mg}, 56 \%)$ were prepared with the respective amounts of $(R)$ - and $(S)$-MTPA (26, $21 \mathrm{mg})$, EDC $(15,17 \mathrm{mg})$, and 4-DMAP $(10,10 \mathrm{mg})$. Crotalionol C 9- $O-(R)-$ MTPA ester (3b): amorphous powder; ${ }^{1} \mathrm{H}-\mathrm{NMR}\left(\mathrm{CDCl}_{3}, 400 \mathrm{MHz}\right) \delta$ $7.51-7.54(2 \mathrm{H}, \mathrm{m}$, aromatic protons), $7.37-7.39(3 \mathrm{H}, \mathrm{m}$, aromatic protons), $5.88(1 \mathrm{H}, \mathrm{d}, J=16 \mathrm{~Hz}, \mathrm{H}-7), 5.75(1 \mathrm{H}, \mathrm{dd}, J=16,7 \mathrm{~Hz}, \mathrm{H}-8), 5.61$ $(1 \mathrm{H}, \mathrm{dq}, J=7,6 \mathrm{~Hz}, \mathrm{H}-9), 4.36(1 \mathrm{H}, \mathrm{br} d \mathrm{~d}, J=6,6 \mathrm{~Hz}, \mathrm{H}-3), 3.53(3 \mathrm{H}, \mathrm{q}$, $\left.J=1 \mathrm{~Hz},-\mathrm{OCH}_{3}\right), 2.00(1 \mathrm{H}$, ddd, $J=12,6,2 \mathrm{~Hz}, \mathrm{H}-4 \mathrm{a}), 1.81(1 \mathrm{H}$, ddd, $J=12,6,2 \mathrm{~Hz}, \mathrm{H}-2 \mathrm{a}), 1.65(1 \mathrm{H}, \mathrm{d}, J=12 \mathrm{~Hz}, \mathrm{H}-4 \mathrm{~b}), 1.59(1 \mathrm{H}, \mathrm{d}, J=12 \mathrm{~Hz}$, $\mathrm{H}-2 \mathrm{~b}), 1.39\left(3 \mathrm{H}, \mathrm{s}, \mathrm{H}_{3}-11\right), 1.38\left(3 \mathrm{H}, \mathrm{d}, J=6 \mathrm{~Hz}, \mathrm{H}_{3}-10\right), 1.16\left(3 \mathrm{H}, \mathrm{s}, \mathrm{H}_{3}\right.$ 13), $0.85\left(3 \mathrm{H}, \mathrm{s}, \mathrm{H}_{3}-12\right)$; HR-ESI-TOF-MS (positive-ion mode) $\mathrm{m} / \mathrm{z}$ : 465.1840 [M+Na $]^{+}$(Calcd for $\mathrm{C}_{23} \mathrm{H}_{29} \mathrm{O}_{5} \mathrm{~F}_{3} \mathrm{Na}, 465.1859$ ). Crotalionol C 9$O$-(S)-MTPA esters (3c): amorphous powder; ${ }^{1} \mathrm{H}-\mathrm{NMR}\left(\mathrm{CDCl}_{3}, 400 \mathrm{MHz}\right)$ $\delta: 7.51-7.54(2 \mathrm{H}, \mathrm{m}$, aromatic protons $), 7.37-7.39(3 \mathrm{H}, \mathrm{m}$, aromatic protons), $5.77(1 \mathrm{H}, \mathrm{d}, J=16 \mathrm{~Hz}, \mathrm{H}-7), 5.68(1 \mathrm{H}, \mathrm{dd}, J=16,7 \mathrm{~Hz}, \mathrm{H}-8), 5.62$ $(1 \mathrm{H}, \mathrm{dq}, J=7,6 \mathrm{~Hz}, \mathrm{H}-9), 4.34(1 \mathrm{H}, \mathrm{brdd}, J=6,6 \mathrm{~Hz}, \mathrm{H}-3), 3.55(3 \mathrm{H}, \mathrm{q}$, $\left.J=1 \mathrm{~Hz},-\mathrm{OCH}_{3}\right), 1.99(1 \mathrm{H}$, ddd, $J=12,6,2 \mathrm{~Hz}, \mathrm{H}-4 \mathrm{a}), 1.79(1 \mathrm{H}$, ddd, $J=12,6,2 \mathrm{~Hz}, \mathrm{H}-2 \mathrm{a}), 1.64(1 \mathrm{H}, \mathrm{d}, J=12 \mathrm{~Hz}, \mathrm{H}-4 \mathrm{~b}), 1.58(1 \mathrm{H}, \mathrm{d}, J=12 \mathrm{~Hz}$, $\mathrm{H}-2 \mathrm{~b}), 1.43\left(3 \mathrm{H}, \mathrm{d}, J=6 \mathrm{~Hz}, \mathrm{H}_{3}-10\right), 1.36\left(3 \mathrm{H}, \mathrm{s}, \mathrm{H}_{3}-11\right), 1.14\left(3 \mathrm{H}, \mathrm{s}, \mathrm{H}_{3}-\right.$ 13), $0.82\left(3 \mathrm{H}, \mathrm{s}, \mathrm{H}_{3}-12\right)$; HR-ESI-TOF-MS (positive-ion mode) $\mathrm{m} / \mathrm{z}$ : $465.1838[\mathrm{M}+\mathrm{Na}]^{+}$(Calcd for $\left.\mathrm{C}_{23} \mathrm{H}_{29} \mathrm{O}_{5} \mathrm{~F}_{3} \mathrm{Na}, 465.1859\right)$.

Enzymatic Hydrolysis of 4 Compound $\mathbf{4}(21.5 \mathrm{mg})$ in $2 \mathrm{ml}$ of $\mathrm{H}_{2} \mathrm{O}$ was incubated with $9.4 \mathrm{mg}$ of $\beta$-glucosidase at $37^{\circ} \mathrm{C}$ for $24 \mathrm{~h}$. The dried reaction mixture was subjected to silica gel $(38 \mathrm{~g}) \mathrm{CC}$ with a solvent system of $\mathrm{CHCl}_{3}(200 \mathrm{ml})$ and $\mathrm{CHCl}_{3}-\mathrm{MeOH}[(19: 1,200 \mathrm{ml})$ and $(9: 1,200 \mathrm{ml})]$, $12 \mathrm{ml}$ fractions being collected. An aglycone, melilotocarpan B (4a) $(7.6 \mathrm{mg})$ was obtained in fractions $25-30$, which was recrystallized from $\mathrm{CHCl}_{3}-\mathrm{MeOH}$ to give $3.2 \mathrm{mg}$ (23\%) of colorless needles. Melilotocarpan B (4a): colorless needles $\left(\mathrm{CHCl}_{3}-\mathrm{MeOH}\right), \mathrm{mp} 111-113^{\circ} \mathrm{C},[\alpha]_{\mathrm{D}}-149.5^{\circ}$ ( $c=0.21$, dioxane); ${ }^{1} \mathrm{H}-\mathrm{NMR}$ (acetone- $\left.d_{6}, 400 \mathrm{MHz}\right) \delta: 7.13(1 \mathrm{H}, \mathrm{d}, J=8 \mathrm{~Hz}$, H-6' $), 6.95(1 \mathrm{H}, \mathrm{d}, J=8 \mathrm{~Hz}, \mathrm{H}-5), 6.71\left(1 \mathrm{H}, \mathrm{d}, J=8 \mathrm{~Hz}, \mathrm{H}-6^{\prime}\right), 6.37(1 \mathrm{H}, \mathrm{dd}$, $\left.J=8,2 \mathrm{~Hz}, \mathrm{H}-5^{\prime}\right), 6.28\left(1 \mathrm{H}, \mathrm{d}, J=2 \mathrm{~Hz}, \mathrm{H}-3^{\prime}\right), 5.53(1 \mathrm{H}, \mathrm{d}, J=6 \mathrm{~Hz}, \mathrm{H}-4)$, $4.31(1 \mathrm{H}, \mathrm{dd}, J=10,3 \mathrm{~Hz}, \mathrm{H}-2 \mathrm{~b}), 3.84\left(3 \mathrm{H}, \mathrm{s},-\mathrm{OCH}_{3}\right), 3.60(2 \mathrm{H}, \mathrm{m}, \mathrm{H}-2 \mathrm{a}$, $3) ;{ }^{13} \mathrm{C}-\mathrm{NMR}$ (acetone- $\left.d_{6}, 100 \mathrm{MHz}\right) \delta: 161.8\left(\mathrm{C}-2^{\prime}\right), 159.7$ (C-4'), 149.0 (C-7), 145.2 (C-9), 136.1 (C-8), 125.9 (C-6'), 121.5 (C-5), 119.1 (C-1'), 115.6 (C-10), 108.4 (C-5'), 106.9 (C-6), 98.6 (C-3'), 79.4 (C-4), 67.6 (C-2), $56.7\left(-\mathrm{OCH}_{3}\right), 40.6(\mathrm{C}-3)$; HR-ESI-TOF-MS (positive-ion mode) $\mathrm{m} / \mathrm{z}$ : $309.0734[\mathrm{M}+\mathrm{Na}]^{+}$(Calcd for $\mathrm{C}_{16} \mathrm{H}_{14} \mathrm{O}_{5} \mathrm{Na}, 309.0733$ ).

Sugar Analyses Glucoses derived on enzymatic hydrolyses of crotalionosides B (2) and C (3) were dissolved in $100 \mu \mathrm{l}$ of $\mathrm{H}_{2} \mathrm{O}$, and an aliquot $(10 \mathrm{ml})$ of each solution was analyzed by HPLC on a Shodex $\mathrm{NH}_{2} \mathrm{P}-50$ column (solvent: $\mathrm{CH}_{3} \mathrm{CN}-\mathrm{H}_{2} \mathrm{O}, 3: 1$; flow rate: $1 \mathrm{ml} / \mathrm{min}$ ) gave peak at $9.5 \mathrm{~min}$ exhibiting positive rotation (JASCO, OR-2090 polarimeter). The peaks were identified with authentic D-glucose. Compounds 4 and $5(0.5 \mathrm{mg}$ each) were hydrolyzed with $100 \mathrm{ml}$ of $1 \mathrm{~N} \mathrm{HCl}$ at $90^{\circ} \mathrm{C}$ for $2 \mathrm{~h}$. The hydrolyzates were partitioned with $100 \mathrm{ml}$ of EtOAc and then $20 \mathrm{ml}$ aliquot of the $\mathrm{H}_{2} \mathrm{O}$ layers were analyzed by HPLC under the same conditions as above to give peaks at
9.5 min exhibiting positive rotation. The peaks were also identified with authetic D-glucose.

Known Compounds Isolated 3 -Hydroxy-5,6-epoxy- $\beta$-ionol 9- $O$ - $\beta$-Dglucopyranoside $\left.(7):[\alpha]_{\mathrm{D}}^{19}-50.7^{\circ}(c=0.88, \mathrm{MeOH}){ }^{6}\right)$ Kaempferol 3-Orobinoside $\left.(\mathbf{8}):[\alpha]_{\mathrm{D}}^{25}-27.1^{\circ}(c=0.75, \mathrm{MeOH})\right)^{7)}$ Robinin $(9)$ : $[\alpha]_{\mathrm{D}}^{25}-113.4^{\circ}$ $(c=0.47$, pyridine $\left.){ }^{8}\right)$

Acknowledgements The authors are grateful for access to the superconducting NMR instrument (JEOL $\alpha-400$ ) at the Analytical Center of Molecular Medicine and an Applied Biosystem QSTAR XL system ESI (Nano Spray)-MS at the Analysis Center of Life Science of the Graduate School of Biomedical Sciences, Hiroshima University. This work was supported in part by a Grant-in-Aid from each of the Ministry of Education, Science, Sports, Culture and Technology of Japan and the Japan Society for the Promotion of Science. Thanks are also due to the Research Foundation for Pharmaceutical Sciences and the Takeda Science Foundation for their financial support.

\section{References}

1) Hatusima S., "Flora of the Ryukyus. Added and Corrected," The Biological Society of Okinawa, Naha, Japan, 1975, pp. 332-333.

2) Hatusima S., Amano T., "Flora of the Ryukyus, South of Amami Island. Enlarged and Revised," 2nd ed., The Biological Society of Okinawa, Naha, Japan, 1994, p. 86.

3) Culvenor C. C. J., Smith L. W., Aust. J. Chem., 19, 1955-1964 (1966).

4) Adams R., Van Duuren B. L., J. Am. Chem. Soc., 75, 4631-4635 (1953).

5) Röder E., Liang X. T., Kabus K. J., Planta Med., 58, 283 (1992),

6) Sudo H., Ide T., Otsuka H., Hirata E., Takushi A., Shinzato T., Takeda Y., Chem. Pharm. Bull., 48, 542-546 (2000).

7) Thierry B., Luc A., Phytochemistry, 25, 536-534 (1986).

8) Ernest W., Hugo E. G., Phytochemistry, 16, 1811-1816 (1977).

9) Ohtani I., Kusumi T., Kashman Y., Kakisawa H., J. Am. Chem. Soc., 113, 4092-4096 (1991).

10) Umehara K., Hattori I., Miyase T., Ueno A., Hara S., Kageyama C., Chem. Pharm. Bull., 36, 5004-5008 (1988).

11) Shitamoto J., Matsunami K., Otsuka H., Shinzato T., Takeda Y., J. Nat. Med., 64, 104-108 (2010).

12) Shitamoto J., Matsunami K., Otsuka H., Shinzato T., Takeda Y., J. Nat. Med., in preparation.

13) Gemal A. L., Luche J. L., J. Am. Chem. Soc., 103, 5454-5459 (1981).

14) De Ville T. E., Hora J., Hursthhouse M. B., Toube T. P., Weedon B. C. L., J. Chem. Soc. Chem. Commun., 1970, 1231-1232 (1970).

15) Miyase T., Ohtsubo A., Ueno A., Noro T., Kuroyanagi M., Fukushima S., Chem. Pharm. Bull., 30, 1986-1991 (1982).

16) Beltrami E., de Bernardi M., Fronza G., Mellerio G., Vidari G., VitaFinzi P., Phytochemistry, 21, 2931-2933 (1982).

17) Augustyn J. A. N., Bezuidenhoudt B. C. B., Swanepoel A., Ferrerira D., Tetrahedron, 46, 4429-4442 (1990).

18) Alvarez A., Delgado G., Phytochemistry, 50, 681—687 (1999). 